This is the peer reviewed version of the following article:

Community Asset Valuations by Non-profit Government Entities

Published in the

Australian Accounting Review

First published: September 2019

which has been published in final form at

https://doi.org/10.1111/auar.12239

This article may be used for non-commercial purposes in accordance with Wiley Terms and Conditions for Self-Archiving." 


\title{
Community Asset Valuations by Non-profit Government Entities
}

\author{
Robert Czernkowski` and Stephen Lim^*
}

Robert Czernkowski is senior lecturer in Accounting at UTS Business School, as well as a member for CPA Australia and IPA. Stephen Lim is senior lecturer at UTS Business School and a member of CPA Australia. The authors are grateful for comments on an earlier draft from participants in the UTS Accounting Seminar Series 2016 and at the European Accounting Association Congress 2017.

\section{Summary at a Glance}

We explore whether management compensation incentives and supply contracting incentives in the Local Government Authorities are related to asset revaluation behaviour. Finding no such relationship, we conclude that the lack of opportunistic self-interest effects suggests that the application of an IFRS framework to local government reporting is not at face value inappropriate.

\begin{abstract}
This paper examines an implication of applying IFRS to the government sector in Australia. We posit both a self-interest and a transparency motivation for local governments effecting revaluations of both Infrastructure Assets and Community Land. The self-interest motivation was expected to manifest as a relationship between the amount of revaluation and CEO (or management team) remuneration. The transparency motivation was expected to result in a relationship between revaluation and the extent of spending on these assets, measured as both quantum of Materials and Contracts Expense, and as the quantum of contracts awarded by the entity above the disclosure threshold. We also speculated that revaluations may be used to signal to state governments a need for additional funds through capital and/or operating grants. At conventional levels of significance, we find no support for these relationships, suggesting that agency motivations at the local government level are either more subtle or non-existent. As local government authorities in our study follow a reporting framework and standardised accounting procedures prescribed by the State government (in compliance with applicable AASB/IFRS standards), financial and public accountabilities are also likely to be a driver for the valuation of local infrastructure assets at fair value, and that this is not likely to be undermined by the opportunistic incentives we have considered.
\end{abstract}

Keywords: revaluation; IFRS; local government; community assets

* $\quad$ Corresponding author: UTS Business School, University of Technology Sydney, CB08.06.103, P.O. Box 123, Broadway NSW 2007; telephone +61-2-9514-3588; Stephen.Lim@uts.edu.au

- UTS Business School, University of Technology Sydney 


\section{Introduction}

There has been a wealth of discussion and critique of the adoption and implementation of accrual accounting in the public sector in various jurisdictions. The earliest adopters were New Zealand and Australia (Lye et al., 2005). Both followed a sector-neutral approach to accounting standard setting, i.e., one set of accounting standards for private, public and non-profit sectors (Hooks and Tooley, 2007). By contrast, Simpkins (2006, p. 100) has pointed out that, in the U.S.A., Canada and the U.K. where separate standard setting boards have been assigned responsibility for the public and private sectors, the needs of public sector users are given more attention. Recent developments have however seen New Zealand standard setters adopting a sector-specific standard-setting approach for the public sector based on International Public Sector Accounting Standards, and the for-profit sector continuing to follow International Financial Reporting Standards (Laswad and Redmayne, 2015).

The critique of the implementation of accrual accounting in the public sector, comprising both Government Trading Enterprises and non-profit government departments and other entities, is not about the use of accrual accounting in itself, but is more concerned with the implementation of accrual accounting as adopted by profitseeking business entities in the private sector, based on the claim of likeness between the two sectors. The proposition that the adoption and development of accrual accounting in the public sector is fundamentally a technical development intended to improve transparency and accountability, or that accounting standard setting is a neutral process, has been disputed in a number of studies (Broadbent and Guthrie, 1992; Guthrie, 1998; Carlin, 2005; Barton, 2005; Elwood and Newberry, 2007; Ryan et al., 2007). In Pilcher (2011), one insightful critique holds that the idea of sector-neutral 
accounting standards is only for the benefit of the standard-setters so that they do not have to address the requirements and issues specific to the public sector. By contrast, some evidence supports the idea that application of accrual accounting in government has been useful. For example, following the adoption of the accrual-based GASB Statement No.34 (Basic Financial Statements—and Management's Discussion and Analysis—for State and Local Governments, 1999), the GASB No.34 Statement of Net Assets was found to provide information relevant for assessing school districts' default risk (Plummer, Hutchinson, and. Patton, 2007). In another study, Baber and Gore (2008) find that accrual-based GAAP requirements reduce municipal borrowing costs.

The Australian sector-neutral approach, applying IFRS to non-business entities, begs the question of whether motivations and other empirically examined phenomena from the business environment apply equally to the non-profit and government sectors. In this paper, therefore, we take a first step in examining the extent of parallels between these sectors on the one hand, and business on the other. As accounting is essentially technically similar across all entities, the issue we grapple with is that of whether the motivational context carries over. In this regard, we examine a key motivational driver in business (managerial remuneration) as well as motivations relating to the nature of contracting in the Australian public sector.

Many have thus questioned the extent to which governance of the public services using a framework drawn from private sector principles is applicable. The applicability hinges upon whether the needs of shareholders in the private sector and stakeholders in public services are the same (Guthrie, 1998; Barton, 2005). Misapplication of the framework drawn from for-profit private sector to the public sector can not only distort the reported "bottom line" of the entities but can also misrepresent a number of financial key 
performance indicators (FKPIs) upon which entity performance is judged (Pilcher, 2009). The former addresses the needs of profit-oriented entities, while the latter is anchored in community service. We focus on a particularly salient issue in local government entities: the treatment of infrastructure assets. Australia's Financial Reporting Council (FRC) acknowledges the fact that IFRSs are written for for-profit entities, and that IFRSs do not deal well with non-exchange transactions (e.g., grants, donations, taxes) and non-cash generating activities (e.g., heritage assets, infrastructure assets) unique to the public sector (FRC, 2012).

To date there has been a number of studies conducted into the infrastructure asset valuation practices of local government authorities (LGAs) in Australia (Walker et al., 1999; Pilcher, 2002; Walker et al., 2004; Pilcher, 2006; Molland and Clift, 2008; Pilcher, 2009; Walker and Jones, 2012), but not empirically as to what drives these practices. Our study examines plausible incentives by LGAs to undertake valuations and revaluations of their major infrastructure assets. The local government sector is economically and socially significant, managing physical assets worth about $\$ 438$ billion and spending around \$34 billion annually, or 6 per cent, of total public sector spending in Australia. In non-metropolitan areas, local government is often one of the largest employers (Australian Local Government Association, 2017). Core infrastructure services, such as roads and bridges, provided by local government (alone or in conjunction with other level of government) are key to facilitating economic activity.

Our study seeks to explore accounting for community and infrastructure assets (excluding heritage assets) that serve functional and largely economic purposes such as 
land, road surfaces, bridges, footpaths, stormwater drainage, swimming pools and other recreational assets.

This study has four objectives. First, we seek to elucidate whether managerial remuneration incentivises valuations and subsequent revaluations of Community Land and local infrastructure assets at fair value by local government authorities. Second, we explore a transparency motivation, based on contracting efficiency, that local government entities recognise valuations and subsequent revaluations of Community Land and local infrastructure assets to advise the local community of the LGA's quantum of assets under management as well as to telegraph future project opportunities to service contract bidders. ${ }^{\text {i }}$ The pattern of outsourcing and the scale and scope of local government activity is of interest to service contract bidders since such information is useful to them in forecasting their own future service contract opportunities with the local authorities and the State government (which finances larger regional development undertakings). More contractor bids for each project serve to make the bidding process more competitive and transparent and offer more options for a local government entity. Third, we explore a plausible relationship between asset revaluation by LGAs and their applications for Operating/Capital Grants from the State government. In the context of local government infrastructure assets, their underlying future benefits are the services that a local government is expected to deliver to its community. To assert their obligations to maintain and enhance infrastructure assets, we posit that asset valuation at fair value and asset revaluation are a means by which LGAs seek to attract more external funding, namely Operating/Capital Grants from the State government. The fourth objective of this paper is to test the proposition that a high ratio for depreciation 
charges as a proportion of total expense is indicative of a not-for-profit public sector entity's propensity to outsource (Carlin, 2005).

Notwithstanding the lack of confirmatory results, our findings - that asset revaluations do not appear to be motivated by opportunistic self-interest - give comfort about the suitability of the financial reporting framework for the LGAs in our study.

\section{Institutional Setting and Background}

Broadbent and Guthrie (2008) conduct a survey of prior studies spanning 20 years into the accounting related specifically to the public sector. They identify and classify these studies into several major categories, including management accounting and control/ budgeting and performance management; external reporting; finance/capital budgeting; auditing/evaluation; and accountability and governance. In relation to the imposition of accounting systems, they emphasise that ' $[\mathrm{a}]$ matter of concern is whether the accounting systems imposed or adopted help to make transparent or obscure the actions of the organisations in question (p.152)'.

In this research, we focus on the key differences between for-profit and public sector (specifically LGA) accounting. Earlier research into public sector accounting identifies a number of key dimensions on which public sector research is conditioned: (1) the applicability of accrual accounting in the public sector; (2) the users of financial reporting in these sector; (3) the way in which financial reporting is used in the sector; (4) possible motivations for the way in which conventional accrual accounting is applied in the sector; and (5) the oftentimes distinct nature of assets held by the sector. We discuss these five research areas in the remainder of this section. 
First, a number of studies question the wisdom of the adoption of for-profit accrual accounting practices by the public sector. Barton (2004) points out that with two exceptions (AAS 16 Financial Reporting by Segments and AAS 22 Related Party Disclosures), all the business accounting standards were applied to the public sector, plus three standards specifically promulgated for the public sector, namely $A A S 27$ Financial Reporting by Local Governments (1996), AAS29 Financial Reporting by Government Departments (1996), and AAS31 Financial Reporting by Governments (1996). These three standards however are still based on the business accounting standards and merely modify them to accommodate some government departmental administrative arrangements.

Christiaens and Rommel (2008) summarise some reasons why applying the concept of profit/loss to the not-for-profit public sector is fraught with serious conceptual issues. First, the concept of profit has no meaning in governments. Since governmental inputs and governmental outputs are not directly related, there can be no concept of profit (Parry, 2005, p. 62). Second, unlike for-profit enterprises, it is not appropriate to judge governments on the difference between their revenues and their costs because their revenues (and net profits) are not their real outcomes. A third serious issue in governmental accrual accounting is the feature of non-exchange transactions. In such transactions there is no direct causal relationship between amounts received and their corresponding costs. Examples are taxes, subsidies, donations, grants, etc. They conclude that accrual accounting in the not-for-profit public sector makes the incorrect assumption that economic outputs represent the level of social services. This assumption is correct however when the government engages in business-like activities. Then, the output is not social but economic and measurable in terms of revenues (and net profits). 
The second dimension of prior research consists of identifying the users of financial reporting information and their respective needs. Mack and Ryan (2006) use a survey methodology to access users of government department general purpose financial reports to study actual users across the entire public sector. Their evidence suggests that general-purpose financial reports are used to satisfy financial accountability and public accountability rather than decision making; that is: users have an accountability focus rather than a 'decision-usefulness' focus. This is inconsistent with the conceptual underpinnings articulated in the AASB and IASB Conceptual Frameworks. Further, Mack and Ryan find that internal users, namely those having a role in the management, operation or governance of the entities, were more predominant than external users. This finding is inconsistent with most of the theoretical studies that emphasise external users, but is consistent with other studies (Coy et al., 1997; and Clark, 2002) that surveyed the actual users of specific reports in an attempt to obtain information about users and their information needs.

Related to this is the third dimension public sector research of how users consume financial information. Priest et al. (1999) find in their surveys of three user groups of local government authorities' annual financial statements that respondents regard performance items and cost of service items as important disclosure items in annual financial statements. Their finding confirms that the type of information included in financial statements by local government is perceived as important information by ratepayers, business groups and service providers.

Bradbury and Scott (2015) find that financial information can be useful to constituents for holding elected officials in New Zealand accountable. Specifically the study tested whether the difference between the actual operating expenditure as reported in the 
annual report and as forecasted is associated with electoral outcomes. They find that accounting performance and the sign of accounting performance (i.e., expenditure overruns) are associated with greater councillor re-election. In brief, the study provides evidence of a link between accounting and electoral results, inferring that accounting information has information content and can convey good/bad news to constituents. The result is also consistent with the argument that the budgeting process, not the financial reporting process, provides the basis for contracting between the governing coalition and constituents (Baber, 1994).

A fourth aspect of the prior research has examined the motivations for applying accounting techniques and for the choices made within that application process. Ultimately the public sector's move to accrual accounting, as well as the application choices made, resolve to a decision to apply different measurement rules and hence to attribute different values to components of the financial statements. A series of studies in Australia has documented the application of accrual accounting in government, and considered the possible motivation underpinning related decisions.

In a study contrasting asset valuation practices of government departments in the state of Victoria and reporting entities in the private sector Carlin (2005) finds that, among public sector entities, depreciation charges as a proportion of total expense were higher than that observed for the private sector sample. Among a series of postulates, Carlin hypothesises that the Victorian government's agenda could serve as a form of outsourcing (or privatisation) by stealth, because the accrual accounting assumptions systematically inflate public sector output costs when compared against private sector alternatives. 
Barton (2009) makes the case for two interrelated factors. First is the adoption of a largely irrelevant business model of accrual accounting rather than one designed to suit public sector needs. Second, a political ideology (as expounded in public choice theory) that advocates downsizing the government and the marketisation of its activities. $\mathrm{He}$ further observes that there are some major problems to be resolved in the application of accrual accounting to the assets used in some areas unique to the public sector. These include many infrastructure, heritage, cultural and environmental assets, and land under roads. 'Meaningful and reliable financial valuations may not be obtainable for these items or be relevant for their good management' (p. 230). Specifically, there are difficult problems in valuing those public sector assets which do not have private sector counterparts, such as community assets, and which are not used for revenue generating purposes.

An early study into asset measurement rules in Australia concluded that the public sector's adoption of current cost measurement rules may arise from a wish for the continued existence of a substantial public sector (Carlin, 2000), in contrast to a desire for a better model of measurement and financial reporting. Carlin also argues that the significance of measurement choices in the public sector extends beyond the appearance and composition of public-sector financial statements, and may have significant implications for contracting and outsourcing choices (Carlin, 2005).

Carlin (2000) finds that Asset Revaluation Reserves as a percentage of both total and net assets are significantly lower for a sample of private-sector entities than for a sample of public-sector agencies, suggesting that there is a far higher reliance on historical cost accounting for private-sector entities. Carlin argues that the private sector had not embraced current cost accounting for two reasons. First, there was no significant 
taxation benefits accrued to adopters of current cost accounting in Australia ${ }^{\text {ii }}$. Second, inflating their asset base under current cost accounting would negatively impact on return on asset ratio.

The adoption of replacement cost valuation methodologies by public sector entities has had the effect of inflating the size of the balance sheets of public sector entities when compared against their private sector counterparts. As noted above, Carlin (2005) finds that depreciation charges as a proportion of total expense was higher for the former. He concludes that inflationary asset valuation techniques may have led to increased accrual charges against the operating statements of Victorian public sector agencies and potentially higher assessed cost of output production. Inflating their balance sheets by adopting replacement cost valuation methodologies could have a direct impact on a variety of resource allocation decisions, including those relating to outsourcing by government departments.

The final, and potentially most contentious, issue in financial reporting by public sector entities relates to the measurement and recognition of infrastructure assets (Walker et al., 1999; Walker et al., 2004; Pilcher, 2005, 2006, 2009; Walker and Jones, 2012) and assets used for cultural, heritage and community purposes (Barton, 2000; Barton, 2005; Broadbent and Guthrie, 2008; Christiaens and Rommel, 2008; Financial Reporting Council, 2012; Aversano and Christiaens, 2014). These are asset categories that are largely unique to the public sector.

While LGA reporting practices suggest that there could be some anomalies and uncertainties surrounding the rating of physical condition of infrastructure assets, Walker, Clarke, and Dean (1999) conclude that these statutory disclosures provided by 
NSW local government are informative and more relevant to external stakeholders and those responsible for asset management in local government. Separately Pilcher (2005) finds that up to 98 per cent of LGAs recorded an error in depreciation of some component of transport infrastructure assets during 1999-2000 and 2002-2003. In a later study, Walker and Jones (2012) report that respondents from telephone and mail surveys, irrespective of their organizational affiliation or professional background, overwhelmingly preferred information about the physical condition of assets, combined with estimates of the current cost of bringing those assets to a satisfactory condition. Another recent local government infrastructure audit report (NSW Premier and Cabinet, 2013) concludes that while the highest incidence of assets that are unable to provide a service were in buildings, bridges, and stormwater drainage, councils appear to have better asset management practices and processes in place for roads and related assets, water supply, and sewer networks.

Heritage, cultural, recreational and environmental facilities and properties are normally preserved and maintained in good condition for the benefit of current and future generations, and they cannot be sold at will by the reporting entity. Their benefits are wholly or largely social in nature. As such the assets could be labelled as social assets, in contrast to the less tangible concept of social capital. One may view social assets to be held in trust for citizens by the government as trustee manager (Barton, 1999). The benefits associated with social assets generally flow to citizens rather than the government.

Subsequent to Carnegie and Wolnizer (1995), Pallot (1997), Carnegie and Wolnizer (1999), and Barton (2000, 2005), Aversano and Christiaens (2014) address the issue of accounting for heritage facilities, which elsewhere are referred to as social assets or 
community assets. Heritage assets differ from other kinds of assets in the value they derive from being impossible to reproduce and substitute, and are highly unlikely to be traded. Such elements are very difficult to handle within a normal accounting system designed for manager of an entity that provides economic services. In brief, they are maintained by the government for cultural, heritage, recreation and other community purposes rather than for the purpose of income generation. In IPSAS 17 Property, Plant and Equipment (International Public Sector Accounting Standards Board), 'heritage assets' are described as assets having cultural, environmental or historical significance. This standard does not require or prohibit their recognition. However, in case a government decides to disclose heritage assets in its financial statements, a number of disclosure requirements (in paragraphs 88 to 94 ) are prescribed by IPSAS 17 such as the basis of measurement, the depreciation method adopted, if any, and a reconciliation of the carrying amount at the beginning and end of the period showing certain components thereof.

In summary, earlier research has demonstrated that financial reporting in the public sector is problematised along a number of dimensions which are not present in the forprofit sector: the applicability of for-profit accounting for non-profits; the nature of users and their needs; the diverse motivations surrounding government entities, compared to the profit-focus of business entities; and the presence of unique asset and transaction types. In spite of problematisation of the sector along these dimensions, there is nonetheless some residual focus on performance, as explicated by Bradbury and Scott's (2015) electoral study.

With regard to the regulatory environment of LGAs in NSW, AAS 27 Financial Reporting by Local Governments (subsequently amended by AAS 27A, AASB 1045) 
requires that local government authorities ascertain the value of land underneath roads in their jurisdiction, undertake a valuation and recognise the asset in each period's statement of financial position. The issues under consideration here are whether this substantial social value to the community can be automatically translated into financial values; and if so, should they be treated as assets of the government for its general purpose financial reports.

In AASB 1051 Land under Roads (2007), land under roads comprises land under roadways, and road reserves, including land under footpaths, nature strips and median strips. In this regard AASB 1051 is applicable to LGAs, which have control of such land within their boundaries. LGAs in NSW include and disclose such land as Community Land in their Notes to the financial statements, in contrast to other operating land, which is valued separately.

Under the Local Government Act (NSW) 1993 and regulations governing statutory reporting, LGAs are required to disclose performance benchmarks relating to services they provided for the fiscal year (1 July - 30 June). In regard to financial reporting, the Local Government Code of Accounting Practice and Financial Reporting (NSW Office of Local Government, 2016 and prior years) provides guidelines on the disclosure of specific items in the financial statements and in the Notes to the financial statements. The Code provides and requires pro-forma financial statements and Notes that are to be strictly adhered to by LGAs. In addition, NSW Office of Local Government (previously NSW Depart of Local Government) issues frequent updates in the form of "Circular to Councils." For instance, Department of Local Government Circular to Councils 09-09 (2009) advised LGAs that the valuation of community land in terms of Australian Accounting Standard AASB 116, Property Plant and Equipment, was to be deferred 
until 30 June 2011 and that the NSW Valuer General's valuations may be used under the revaluation model to represent fair value for the revaluation of community land under clause 31 of AASB $116^{\mathrm{iii}}$.

Given the partial similarity in motivations between business and government, together with unique aspects of the public sector, we therefore explore whether LGA reporting behaviour is driven by conventional agency incentives and unique government-sector incentives. We aim to provide an explanation for the valuation and subsequent revaluation of local infrastructure assets at fair value, excluding heritage assets, by local government authorities.

\section{Hypothesis Development and Research Method}

Prior studies that surveyed the actual users of specific reports (Coy et al., 1997; Clark, 2002; Mack and Ryan, 2006) found that internal users, namely those having a role in the management, operation or governance of the entities, were more predominant than external users. In the context of local government authorities, job mobility of management and other employees is much enhanced when employees in one section within a local government authority is well informed of the activity undertaken by other sections. Likewise inter-entity job mobility and opportunity are vastly improved when information on activity and performance of each section is disclosed. From the local government's perspective, such disclosure provides useful information in attracting outside talents to the employ of the local government authority.

With regard to external users of local government annual reports, Priest et al. (1999) surveyed ratepayers, apart from business people and service providers (contractors) engaged by a local government, as users of annual reports. For our study, we focus on 
service contractors as the major user group who could be expected to be interested in specific information disclosed in the annual report such as local government's Materials and Contract expense, and Contracts Awarded above a threshold (disclosing the winning contractors and the amounts awarded for the fiscal year). We argue that service contractors are interested in the pattern of outsourcing and the scale and scope of a local government's activity since such information is useful to the contractors in projecting their future contract opportunities with the local government and State authorities. These outsourcing activities would include road and building work maintenance, development, construction and other related extension works.

It is essential to clarify that, in our exploratory context, hypotheses are specified in order to provide an investigative frame. Given the paucity of research into incentives in local government, we do not posit them as forcefully as would be done in a for-profit context.

\subsection{Asset Revaluation from an Efficient Contracting Perspective}

In line with the efficient contracting perspective (Holthausen, 1990; Emanuel et al., 2003), we pose that the valuation and subsequent revaluation of Community Assets and the disclosure of major contracts awarded by local government authorities minimise agency costs amongst several interested parties, namely the local government management, the service contractors, and supervisory agencies. First, the range and scope of future outsourced projects published by an LGA can be gauged and extrapolated from existing Community Assets under a local government's jurisdiction. More contractor bids for each project serve to make the bidding process more competitive and afford more options for the authority. Second, for a given project, the service contractors would be able to submit a realistic bid price based on similar past 
valuations of a community asset and past contracts awarded. Third, supervisory and investigative agencies such as the Office of Local Government (NSW) and the Independent Commission against Corruption (ICAC) would welcome more direct monitoring by the public and others advocating greater scrutiny and transparency in local government reporting with regard to the tendering and awarding of contracts by local government entities for outsourced services. In summary, the efficient contracting framework yields the following hypotheses:

H1a: Asset revaluation of community land by local government entities are positively related to the service contracts awarded.

H1b: Asset revaluation of infrastructure (community) assets by local government entities are positively related to the service contracts awarded.

H1c: Asset revaluation of community land by local government entities are positively related to the materials and service contract expense.

H1d: Asset revaluation of infrastructure (community) assets by local government entities are positively related to the materials and service contract expense.

Under the Local Government Act (NSW) 1993 and regulations governing statutory reporting, local government entities are required to disclose Service Contracts Awarded above threshold (commonly \$150,000). Further, Local Government Code of Accounting Practice and Financial Reporting (NSW) provide guidelines on the disclosure of specific items in the financial statements and in the Notes to the financial statements of local 
government entities, including Depreciation, Amortisation \& Impairment under Note 4(d).

Community Assets comprise Community Land and local Infrastructure (Community) Assets. Our definition of Community Assets is much narrower than that of Barton's (2000) in that we specifically exclude heritage and cultural assets. We exclude such items for two reasons. First, the concern over heritage asset valuation and recognition (Barton, 2000) involving larger structures and environment is unlikely to be relevant in the context of our study. A local government entity is not the appropriate depository to be entrusted with the management of such specialised (and often massive) assets. Second, 'Heritage Collections' held by a local government entity are incidental and immaterial relative to its major operating assets. We further exclude operational land and other operational items such as minor Plant and Equipment, office equipment, furniture and fittings, and non-specialised buildings as such common assets can be disposed of or replaced at the discretion of a local government authority in the same manner had they been under the control of any business entity. As in the case of Heritage Collections, such operational assets held by a local government entity are immaterial relative to its major operational community assets.

The definitions and measurements relating to the variables in the above hypotheses are as follows:

Community Land comprises public parks, playgrounds, sports grounds, and Land under Roads. Local government entities recognise and disclose community land at fair value (and not at cost) at end of each reporting period. Land under Roads comprises land under roadways, and road reserves, including land under footpaths, nature strips and 
median strips. Land under Roads is thus a sub-category of Community Land, but not separately disclosed by local government entities in the Notes to their financial statements. As valuation and revaluation of land under roads are not separately disclosed, we adopt the broader measure of community land for our tests.

Infrastructure Community Assets consist of road surfaces, bridges, footpaths, stormwater drainage, swimming pools and other recreational assets. Local government entities also recognise and disclose their infrastructure community assets at fair value (and not at cost) at end of each reporting period.

Service Contracts Awarded disclosure by local councils in their annual reports is a statutory requirement under Local Government Code of Accounting Practice and Financial Reporting (NSW). The dollar amount of each contract is disclosed, as well as the identity of the winning contract bidder.

Materials and Contract Expense is disclosed by local councils as a separate line item in their operating statement and further details are provided in the Notes to the financial statements.

Community land revaluation is measured as the difference between two successive years' carrying values of community land, excluding any addition and disposal. Infrastructure community assets revaluation is likewise the difference between two successive years' carrying values of infrastructure community assets, excluding any addition/disposal, transfer in/out, and depreciation for the fiscal year.

Hypothesis 1 is tested by estimation of the following models: 


$$
\begin{aligned}
& S C A_{i, t}=\alpha+\beta_{1} \cdot C O M M L A N D R E V A L_{i, t}+\beta_{2} \cdot \operatorname{COMMLAND}_{i, t-1}+
\end{aligned}
$$

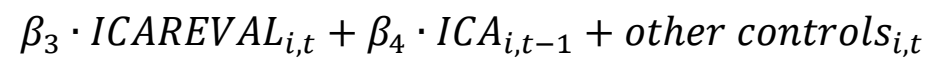

$$
\begin{aligned}
& M C E_{i, t}=\alpha+\beta_{1} \cdot C O M M L A N D R E V A L_{i, t}+\beta_{2} \cdot \operatorname{COMMLAND}_{i, t-1}+
\end{aligned}
$$

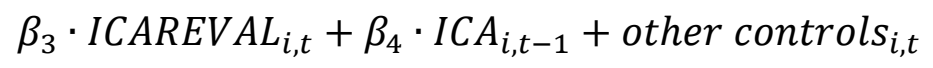

where:

$$
\begin{array}{ll}
S C A & =\text { Service Contracts Awarded } \\
M C E & =\text { Materials and Contract Expense } \\
\text { COMMLANDREVAL } & =\text { amount of Community Land Revaluation } \\
\text { COMMLAND } & =\text { balance of Community Land } \\
\text { ICAREVAL } & =\text { amount of Infrastructure Community Assets } \\
& \text { Revaluation } \\
I C A & =\text { balance of Infrastructure Community Assets }
\end{array}
$$

The existence of effects hypothesised exists if $\beta_{1}$ and $\beta_{3}$ coefficients are significant. The structure of the models, in the context of signalling contracting opportunities, reflects the ability of revaluation to flow through into the award of greater amounts of external contracts by dollar quantum above the reporting threshold (SCA) and in total (MCE). We acknowledge that the existence of other users of financial reports, such as internal users and regulatory agencies, may bias against finding confirmatory results, potentially yielding less significant results.

Note that this model is a simplified model. As is apparent in our results section, we introduce lagged effects on the right hand side of the model. We do this because it is 
difficult to assert unequivocally that financial information in a given period is used to make decisions about outsourcing or bidding for contracts immediately. Indeed, it is more likely that the information effect takes some time to percolate out of the entity to information users.

\subsection{Asset Revaluation and Opportunistic Incentives}

An alternative to efficient contracting explanation of the valuation and revaluation practices of community assets by local government is that of opportunistic behaviour in accounting choice. Watts and Zimmerman (1990) advocate however that in future 'the empirical tests can no longer assume accounting choice is made for either efficiency or opportunistic reasons. Both must be incorporated into the tests.' By contrast, Emanuel et al. (2003) argue that 'even if an accounting choice appears to be opportunistic or is indeed purely opportunistic, we can still view accounting as an efficient contracting technology’ (p. 163). To some degree opportunism will exist, but one could not dismiss accounting systems and accounting choices as having not been developed from an efficient contracting framework. It is well accepted the thrust of the institutional economics literature is that of efficiency, and 'it would be inconceivable to generate any kind of accounting theory without fitting it within that efficiency framework' (p.163).

Based on the foregoing observations of Watts and Zimmerman (1990) and Emanuel et al. (2003), we seek to test if remuneration rewards incentivise management of local government entities to opportunistically value and subsequently revalue Community Land and local infrastructure assets at fair value.

H2a: Management remunerations incentivise community land revaluation at fair value by local government entities. 
$\mathrm{H} 2 \mathrm{~b}$ : Management remunerations incentivise infrastructure community assets revaluation by local government entities.

We acknowledge that any test of agency incentives will be a joint test of those incentives and of other (omitted variable) effects. To tease out such effects would require much larger datasets than we have available for this study, and so our results will need to be interpreted bearing in mind this impediment to internal validity.

In each of the above hypotheses, we estimate multivariate (fixed effects) OLS regressions using the following empirical models:

$$
\begin{aligned}
& \text { CEO_REMUN } N_{i, t}=\alpha+\beta_{1} \cdot \text { COMMLANDREVAL } L_{i, t}+\beta_{2} \cdot \text { COMMLAND }_{i, t-1}+
\end{aligned}
$$

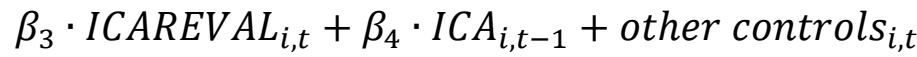

$$
\begin{aligned}
& M G T_{-} R E M U N_{i, t}=\alpha+\beta_{1} \cdot C O M M L A N D R E V A L_{i, t}+\beta_{2} \cdot C_{O M M M A N D} D_{i, t-1}+
\end{aligned}
$$

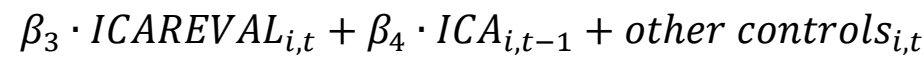

where:

$$
\begin{array}{ll}
C E O \_ \text {REMUN } & =\mathrm{CEO} \text { total remuneration } \\
M G T_{-} R E M U N & =\text { total remuneration paid to the entire management team } \\
& \text { (including the CEO). }
\end{array}
$$

The lagged effect reflects the causal direction of the relation, wherein a management team seeks to undertake a revaluation in anticipation of being able to (in future) derive an enhanced remuneration package.

Local government entities are required to disclose the CEO remuneration and Senior Staff remuneration under the Local Government Act (NSW) 1993 and regulations governing statutory reporting. The Senior Staff remuneration is generally not disclosed 
individually, but disclosed collectively as a group. The remuneration reported includes the manager's superannuation, bonuses, and all other benefits.

\subsection{Asset Revaluation and Operating/Capital Grants}

There are many regional development projects that are beyond the financial resources of LGAs' internal sources of income, chiefly from Rates revenue (local tax) and servicebased fees. A major external source of income for many LGAs is Operating/Capital Grants funded by the Federal Government and administered by the State Government through a Local Government Grants Commission (2015). In 2013 the New South Wales Treasury Corporation (TCorp) undertook a comprehensive review of the financial sustainability of NSW local government sector. Among its major findings is that councils' deteriorating financial performance had been occurring for some time and this had led to a gradual weakening of the local government sector. The future sustainability of Councils is dependent upon generating sufficient funds to meet the costs of maintaining and renewing assets to deliver services.

With regard to local government infrastructure assets, TCorp (2013) identified two key issues of utmost concern. First, an asset maintenance gap exists, namely an annual shortfall in spending on asset maintenance has persisted in recent years. Second, there exists a continuing and substantial Infrastructure Backlog across all Councils. TCorp concluded that these factors together with councils' worsening financial performance, if not corrected, will lead to further deteriorating financial strength and ultimately a lower quality of assets and hence services that can be delivered by the sector.

Assets embody future benefits, and in the context of local government infrastructure assets, the future benefits are the services that a local government is expected to deliver 
to its community. In line with their obligations to maintain and enhance infrastructure assets to provide the expected level of service to the community, we posit that asset revaluations are a means by which LGAs seek to explicate their needs for additional funding and to attract Operating/Capital Grants from the NSW Local Government Grants Commission. However, there are specific circumstances wherein capital grants could be awarded on the basis of emergency, such as the needs occasioned by property losses from bush fires and floods, which would trigger downward revaluation of assets. $^{\text {iv }}$

H3a: Government Grants incentivise community land revaluation by local government entities.

H3b: Government Grants incentivise infrastructure community assets revaluation by local government entities.

We test these relations by estimating the following models:

$$
\begin{aligned}
& \text { OPGRANT }_{i, t}=\alpha+\beta_{1} \cdot \operatorname{COMMLANDREVAL} L_{i, t}+\beta_{2} \cdot \operatorname{COMMLAND}_{i, t-1}+
\end{aligned}
$$

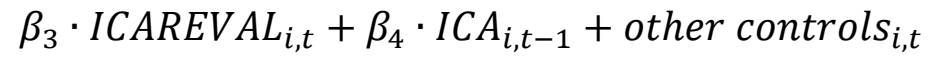

$$
\begin{aligned}
& \text { CAPGRANT }_{i, t}=\alpha+\beta_{1} \cdot \text { COMMLANDREVAL }_{i, t}+\beta_{2} \cdot \text { COMMLAND }_{i, t-1}+
\end{aligned}
$$

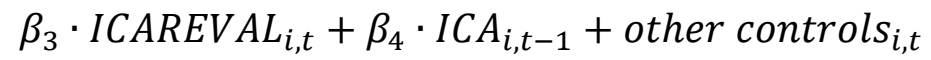

where:

OPGRANT = Total Operating Grants received by the LGA during the year

$C A P G R A N T=$ Total Capital Grants received by the LGA during the year 


\subsection{Testing for Government Entities' Propensity to Outsource}

We also seek to test findings by Carlin (2005) that among the Victorian government's public sector entities, depreciation charges as a proportion of total expense were higher than that observed for the private sector sample. Carlin (2005) concludes that the Victorian government's agenda could serve as a form of outsourcing (or privatisation) by stealth, because the accrual accounting assumptions systematically inflate public sector output costs when compared against private sector alternatives. We reason that if a high ratio for depreciation charges as a proportion of total expense is indicative of a not-for-profit public sector entity's agenda to outsource, there exists a positive correlation between a high ratio for depreciation charges as a proportion of total expense and the value of the service contracts awarded by a public sector entity.

H4a: Depreciation charges as a proportion of total expense of local government entities are positively related to the service contracts awarded.

In an earlier study, Carlin (2000) finds that Asset Revaluation Reserves as a percentage of both total and net assets are significantly lower for the sample of private-sector entities than for the sample of public-sector agencies, suggesting that there is a far higher reliance on historical cost accounting for private-sector entities. He falls short however of charging the public sector and government with having an agenda of outsourcing (or privatisation) by stealth. Nonetheless Carlin's (2000) finding, while precedes, also resonates with the tenor of his later study (Carlin, 2005). We seek to extend Carlin's (2000) finding and examine if Asset Revaluation Reserves as a 
percentage of local government entity's total assets are correlated with service contracts awarded.

H4b: Asset Revaluation Reserves as a proportion of local government entity's total assets are positively related to the service contracts awarded.

Hypothesis 4 is tested by estimating the following models:

$$
\begin{aligned}
& D_{E P N_{-} T E_{i, t}}=\alpha+\beta_{1} \cdot S C A_{i, t-1}+\text { other controls } \\
& \text { ARR_t }_{-} T A_{i, t}=\alpha+\beta_{1} \cdot S C A_{i, t-1}+\text { other controls } \\
& i, t
\end{aligned}
$$

where:

$D E P N \_T E=$ Depreciation charges as a proportion of total expense

$A R R \_T A=$ Asset Revaluation Reserves as a percentage of total assets

Depreciation charges, total expense, total assets, service contracts awarded, and asset revaluation reserves are extracted directly from a council's financial statements.

\subsection{Data and Method}

We collected data spanning eight years (2008-2015) from the top quartile of 152 general-purpose local government councils in NSW ranked by their total assets as of June 2015. The final sample size was 43. The cut-off year of 2008 is chosen since subsequent to AASB 1051 Land under Roads applicable from 1 July 2008, local government entities (and State Roads and Traffic authorities) have the option to derecognise some or all of the carrying value of land under roads acquired prior to 1 July 2008. The tail end of the study period, namely 2015 , lends itself readily since 
major amalgamations among LGAs in NSW took place in 2016, which would render continuity and consistency of data problematic.

The models described above are tested using regression techniques incorporating fixed effects for both 'firms' (i.e., local government authorities in the sample) and years. The logarithm of total assets (LogTotalAssets) is included as a control in each test.

\section{Results and Conclusions}

Table 1 reports the key descriptives. We note in particular that there are few Community Land Revaluations disclosed by the sample reporting entities. Correlations of key variables are presented in Table 2 .

\subsection{Main tests}

We postulate in hypothesis 1 that revaluation of community land and infrastructure by Local Government Authorities (LGAs) is related to the extent of contracts awarded by LGAs. As the amount of such contracts necessarily undertaken is a function of the amount of assets under management, revaluation of such assets strengthens transparency by demonstrating the amount of assets which the LGA manages.

Our results addressing Hypothesis 1 are shown in Tables 3 and 4. In Hypothesis 1, the postulated relationship involves the extent of revaluation of Community Land and of Infrastructure Assets in general. As noted above, few LGAs disclose separately the revaluation of Community Land component. For this reason, we report regressions estimated including and excluding the Community Land variables. When excluded, we obtain a larger number of observations with available data for all variables. 
The regressions are estimated with fixed effects for LGAs and years. The key variables are COMMLANDREVAL (the change in the revaluation reserve for Community Land, where available) and ICAREVAL (the change in the revaluation reserve for total Infrastructure Assets). The dependant variables are SCA (sum of Contracts Awarded over reportable threshold) and MCE (Materials Contracts and Expenses) ${ }^{\mathrm{v}}$.

These variables and the control variables are defined as follows:

Variables standardised by Total Assets in tests ${ }^{v i}$ :

$S C A=$ Total Sum of Contacts Awarded over the reporting threshold for LGAs $(\$ 150,000)$

$M C E \quad=$ Materials and Contracts Expense for the current financial year, from the Income Statement

MCP $=\quad$ Cash payments related to Materials and Contracts

Expense for the current financial year, from the Statement of Cash Flows

COMMLANDREVAL = the net change in any revaluation reserve relating to Community Land

COMMLANDREVAL_t $t=$ the net change in any revaluation reserve relating to Community Land lagged one period

COMMLAND_t1 $\quad=\quad$ Community Land balance at the start of the financial year

COMMLAND_t2 $=$ Community Land balance lagged one period 
ICAREVAL

ICAREVAL_t 1

ICA_t1

$I C A \_t 2$

CFOnet

Employee Expenses

EquityTotal

RevenueBudgeted

RevenueTotal $=$

Population

PopPerEmp
NoEmployees
$=$ the net change in the revaluation reserve relating to Infrastructure Assets

$=$ the net change in the revaluation reserve relating to

Infrastructure Assets lagged one period

$=$ Infrastructure Assets at the start of the financial year

$=\quad$ Infrastructure Assets lagged one period

$=$ Net operating cash flows of the current year from the Statement of Cash Flows

$=$ Employee Related Expenses from the Income

Statement

$=\quad$ Net assets of the LGA

$=$ Revenue budgeted by the LGA for the current period

Variables not standardised by Total Assets:

$=\quad$ Number of full time equivalent employees of LGA at end of the year

$=\quad$ Population of LGA in the given year (from Australian Bureau of Statistics)

$=$ Population divided by Number of Employees 
From Table 3, we see that there is no relationship between revaluations of either Community Land or Infrastructure Assets for LGAs that report both of these items. However, when the sample is extended by not requiring the Community Land variables to be present, we do find a significant positive effect $(p<0.10)$ of Infrastructure revaluations on $M C E$ (Materials and Contracts Expense). This contemporaneous relationship ${ }^{\mathrm{vii}}$ suggests that the presence of higher maintenance costs could be interpreted as the LGA managing a larger quantum of assets (perhaps as a prelude to seeking additional funding). No effect however is detected on the quantum of contracts awarded, suggesting only partial support for H1. Since contracts awarded and MCE are essentially capturing the same phenomenon, we suspect that the difference may be due to the incompleteness of the former, as SCA only captures outsourcing above a threshold, whereas MCE captures total spending.

It is possible that the relationship between revaluations on the one hand, and awarding contracts on the other, is one that involves some delay. For example, an LGA may feel more comfortable in awarding the relevant number of contracts once its need for them has been clearly demonstrated by a set of published financial statements, making public a more appropriate valuation of the assets under management.

Accordingly, in Table 4 we report the results of introducing two lagged revaluation variables (COMMLANDREVAL_t1 and ICAREVAL_t1) and the related opening-balance controls (COMMLAND_t2 and $\left.I C A \_t 2\right)$. We observe a negative relationship between MCE and Community Land revaluations only for the lagged measure $(p=0.011)$, while only the lagged version of ICAREVAL has a positive coefficient $(\mathrm{p}=0.013)$. 
In summary, therefore, our hypothesis 1 regarding a relationship between disclosure of fair values through the revaluation process and the amount of expenditure related to those assets $(S C A, M C E)$ is - at best (the coefficient on ICAREVAL in Table 3) - only supported very tenuously, in limited circumstances.

In hypothesis 2 , we postulate a relation between revaluation activity and the remuneration of top management: $C E O_{-} R E M U N$, measuring the remuneration of the CEO (howsoever described) and $M G T \_R E M U N$, measuring the total remuneration of management. Similarly to our test of Hypothesis 1, we estimate fixed effects models over both the restricted sample requiring non-missing Community Land revaluation, and over a larger sample without this restriction. The results, tabulated in Table 5, indicate no relationship whatsoever between revaluations and either remuneration variable. Table 6 , reporting regressions estimated using lagged revaluations, similarly finds no response except for a negative one with lagged Community Land revaluations, for the small subsample containing these.

Our main evidence is consistent with their being no relation between revaluation activity and management remuneration. In other words, the ability to derive higher remuneration does not appear to be a driver of revaluation activity. A plausible explanation for absence of correlation is that the remuneration of the $\mathrm{CEO}$ and senior executives of LGAs are largely determined by an independent government Tribunal, and the narrow range within each level of remuneration is not sufficiently substantial to be a driver for asset revaluation. 
It is clear, from the above, that revaluation in Local Government reporting entities is not driven by the usual motivations which are attributed by agency theory to accounting activities in the private sector.

One of the main stakeholders in local government is the granting agencies of state government. We posit in hypothesis 3 a relationship between revaluation behaviour and the quanta of capital and operating grants respectively. Table 7 reports estimations of explanatory effects of the various revaluation variables on both of these grant types. In columns (1) and (2) we report the results for Operating and Capital grants respectively for the subsample including Community Land revaluations. In the remaining columns we drop the restrictions that these revaluations need to be present, and introduce a lag of Infrastructure Asset revaluations. We find significant results in only one of these models: for the subsample of Community Land revaluers, there is a strong negative association $(\mathrm{p}<0.01)$ between Capital Grants and Community Land Revaluations, and a strong positive association $(\mathrm{p}<0.01)$ between Infrastructure Asset revaluations and Capital Grants.

Particularly intriguing is that these results do not hold across the larger sample. The councils undertaking revaluations of Community Land (with the exception of two LGAyears) are all in the Sydney metropolitan area. Given that these are councils likely to have highly valuable infrastructure and community land, the relationship with Community Land is unsurprising (land as such does not require much capital maintenance). In contrast, highly valuable infrastructure is likely to require costly development, and so its value (or revalued 'value') is more likely to constitute a salient signal to granting agencies. 
In hypothesis 4, we examine an alternative motivation for accounting behaviour in LGAs: that high depreciation expenses and high revaluation reserves provide an excuse to outsource. Table 8 Panel A reports the results of three regressions using contemporaneous measures: $D E P N \_T E$ (depreciation as a proportion of total expenses) against $S C A, A R R \_T A$ (Asset Revaluation Reserve as a proportion of total assets) against $S C A$, and $S C A$ against both $D E P N_{-} T E$ and $A R R \_T A$. Although no relationship obtains on DEPN_TE, a relationship between ARR_TA and SCA_TA is dependent on the structure of the model. When regressing outsourcing (SCA_TA) against cumulative revaluation (ARR_TA) and controls, no result obtains (column 3). However, when the controls are used to remove variation in ARR_TA rather than SCA_TA (column 2), a strong positive relationship occurs, suggesting that service contracts are associated with the extent of revaluations.

Note that these results implicitly assume that signalling (accounting) and response (outsourcing) happen almost concurrently. It is possible that the effect is delayed. Accordingly, in Table 8 Panel B we report the relation between SCA and one-period lagged values of direct revaluation measures. Similar to Panel A, we continue to observe the absence of any relationship between contacts awarded and (in this case, lagged) values of depreciation and Asset Revaluation Reserve. In addition, regressing ARR_TA against lagged SCA (not reported; similar to Table 8, Panel A, column 2) also yields no significant relation.

Overall, therefore, we find some evidence for a relationship between revaluations and service contracts awarded, but only when concurrent measures of these variables are examined. In order to assert a causal relationship, we would expect a lagged relationship 
between revaluation and SCA_TA. The absence of such a relationship prevents us from concluding any causal relationship

\subsection{Robustness and the effect of Size}

To test our results for robustness, we also estimated fixed effects models:

- with all variables raw (rather than standardised by Total Assets) for the LGA/year;

- $\quad$ with all variables standardised by Total Assets for the LGA/year, also including the raw total assets as a size control;

- $\quad$ with all variables standardised by Total Assets as above, but also including lagged revaluation from the previous two years (rather than one year); and

- with all variables standardised by Total Assets as above with the raw total assets as a size control and winsorising all variables at both $1 \%$ and $10 \%$

Our basic results are qualitatively representative of robustness tests undertaken. Thus, we conclude that there is no systematic relationship between revaluation and management compensation and contracts awarded (whether measured by Materials Contracts Expense or Sum of Contracts Awarded).

Generally, if a strong effect exists, a linear model is likely to find it. However, if there are non-linearities in the economic relationship, a linear model may well obstruct its presence. Local Government Authorities in New South Wales are quite different in size. In our sample, the top LGA is roughly a factor of 10 larger (by total assets) than the lowest LGA. It is likely that incentives and organisational culture will vary substantially 
between large and small LGAs. If in fact there is a size difference, it would be detected by examining the extrema of our sample. Accordingly, we split our entire data set into quartiles (by total assets in the given LGA/year), discard the second and third quartile, and re-run the basic tests for the top and bottom quartiles.

The results (using winsorised variables) are reported in Tables 9, 10, 11 and 12. In relation to hypotheses 1 and 2, we find:

- a significant positive coefficient on unlagged Infrastructure revaluation (ICAREVAL) on Materials Contracts Expense (MCE) in large LGAs (Table 9, Panel B, $\mathrm{p}<0.05)$;

- a significant positive coefficient on 1-year lagged Infrastructure revaluation (ICAREVAL_t 1$)$ on Management remuneration $\left(M G T \_R E M U N\right)$ in large LGAs (Table 10, Panel B, $\mathrm{p}<0.01$ );

Clearly, support for Hypotheses 1 and 2 is present but not pervasive.

Table 11 reports the determinants of grants by quartile. Except for a weak positive relation between current year revaluations of infrastructure (ICAREVAL) and Capital Grants (Table 11, Panel A, $\mathrm{p}<0.10$ ) for small LGAs, there is no other effect. This indicates that there is some relationship between revaluations and capital grants, but this effect is contemporaneous, and so attribution of causality would be difficult, especially in the absence of any significance on the lagged variable.

For hypothesis 4, Table 12 reveals weak evidence for a significant positive relationship between SCA (standardised by Total Assets, SCA_TA) and the percentage of Total Expenses constituted by depreciation (DEPN_TE), for just the top quartile of LGAs by total assets. However, this is marginally significant $(\mathrm{p}=0.052)$ only in the case where the 
dependant variable is depreciation but not where SCA is the dependent variable. This suggests that the effect, if any, is quite weak.

That the relationship between SCA, depreciation and revaluation is sensitive to model structure (Table 8) and winsorisation (Table 12) suggests that there is no systematic relationship. For example, the absence of any relationship between revaluation and SCA after winsorisation suggests that the winsorised extrema are likely driving any relationship, rather than it subsisting through the entire dataset. Accordingly, we cannot conclude that there is no systematic relationship between depreciation and revaluation in the one hand, and SCA on the other.

\subsection{Conclusions and Limitations}

We examine an implication of applying IFRS to the public sector in Australia, positing both a self-interest and a transparency motivation for local governments undertaking revaluations of both Infrastructure Assets and Community Land.

The self-interest motivation was expected to manifest as a relationship between the amount of revaluation and CEO (or management team) remuneration. We theorised that increased measures of assets under management, whether in terms of revaluation increases, or as quantum of ongoing depreciation, may be an underpinning rationale for justifying higher pay for the CEO in particular, or management team in general. Similarly, we posited that revaluations of assets would provide a signal to funding sources (i.e., state governments) that a substantial amount of assets required greater capital grants for asset enhancement.

The transparency motivation was expected to result in a relationship between revaluation and the extent of spending on these assets, measured as both quantum of 
Materials and Contracts Expense, and as the quantum of contracts awarded by the entity above the disclosure threshold. Under this motivation, we argue that local government entities have an informational incentive to mark assets to fair value. By marking assets to fair value, they are able to justify the extent of spending incurred and contracts issued in relation to the ongoing operation of those assets.

At conventional levels of significance, we find no pervasive support for these relationships, suggesting that motivations at the local government level are either more subtle or non-existent. The lack of significant relationships is not however inconsistent with findings in Mack and Ryan (2006) and Coy et al. (1997). Mack and Ryan's evidence, drawn from a survey of actual users of government department general purpose financial reports, suggests that general-purpose financial reports are used to satisfy financial accountability and public accountability rather than decision making. Our results, within our empirical context, are supportive of the lack of motivation “contamination" of this reporting process.

Using a survey of annual report recipients, Coy et al. (1997) conclude that evidence from the NZ tertiary education sector suggests that internal and within-industry users are more active users of annual reports than external recipients. As the local government authorities in our study follow a reporting framework and standardised accounting procedures prescribed by the State government (in compliance with applicable AASB/IFRS standards), financial and public accountabilities are likely to be a driver for the valuation and subsequent revaluation of local infrastructure assets at fair value. Thus our findings - that asset revaluations do not appear to be motivated by opportunistic self-interest - lends support to the suitability of the financial reporting framework for local government governance. 
The implications of our study are restricted to the local government context. Data constraints, including sample sizes, do not allow the testing of complex interplays of incentives. Nonetheless, within this limitation, this study contributes to documenting whether Australian local government financial reporting is susceptible to opportunistic behaviour. 


\section{Endnotes}

i Bradbury and Scott (2015) find in New Zealand that ratepayers are likely to use secondary sources.

ii This comment by Carlin of course ignores the point that financial reporting decisions do not necessarily have any impact on tax reporting outcomes, given the quite distinct nature of financial accounting and tax accounting.

iii A reviewer suggested that our hypotheses may lack support due to other incentives or regulatory changes. In relation to the first issue, our sample size restricts the extent of interactions (and institutional nuances) able to be modelled within the context of NSW Local government. We acknowledge, therefore, that our tests are essentially joint tests with the effects of omitted variables. Given these sample constraints, this research should be read as documenting behaviours, even though - for framing purposes - we express this as hypothesis testing.

In relation to the second issue, we considered whether the extent of revaluations had changed around the 2011 fair value implementation year regulated by the 2009 DLG Circular to Councils 09-09, requiring councils to value assets at fair value from 2011. A comparison of mean revaluations for community land, infrastructure and total revaluation reserve change (not reported) did not show any evidence of significant differences before/after 2011.

iv We acknowledge suggestion from a reviewer to this aspect of potential downward revaluation. 
As a robustness check, we also test Materials Contract Payments, which is the amount of cash payments made in relation to Materials Contracts and Expenses. As the results are qualitatively the same as for Materials Contracts and Expenses, they are not reported.

Our tests use versions of these variables standardised by Total Assets, identified in our results tables by appending a suffix of "_TA". For clarity, we generally omit the suffix in our discussion. A reviewer also suggested that perhaps our failure to find contemporaneous results may be due to LGAs being on a "revaluation treadmill". We investigated (results not tabulated) whether there was any time series relationship between successive revaluations, both for community land and for infrastructure assets, as well as for total revaluation. Except for a negative correlation between community land revaluation and its one-year lag, no relationship existed. In particular, there was no "treadmill" in the sense of a positive correlation between successive revaluations. 


\section{REFERENCES}

Australian Accounting Standards Board, AAS 16 (1987), Financial Reporting by Segments.

Australian Accounting Standards Board, AAS 22 (1993), Related Party Disclosures.

Australian Accounting Standards Board, AASB 1045 (2002), Land Under Roads: Amendments to AAS 27A, AAS 29A and AAS 31A.

Australian Accounting Standards Board, AASB 116 (2015 and prior years), Property, Plant and Equipment. Australian Local Government Association, 'Local Government and the Economy', http://councilreferendum.com.au/alga-pages/12312 (retrieved 16 June, 2017).

Australian Local Government Association, 'Facts and Figures on Local Governments in Australia', http://alga.asn.au/?ID=59 (retrieved 16 June, 2017).

Aversano, N., \& Christiaens, J. (2014). Governmental financial reporting of heritage assets from a user needs perspective. Financial Accountability \& Management, 30(2), 150-174.

Baber, W.R. (1994) 'The influence of political competition on governmental reporting and Auditing', Research in Governmental and Nonprofit Accounting 8: 109-27.

Baber, W.R. and Gore, A.K. (2008) 'Consequences of GAAP disclosure regulation: Evidence from municipal debt issues', The Accounting Review, 83: 565-92.

Barton, A. D. (1999) ‘A Trusteeship Theory of Accounting for Natural Capital Assets’, Abacus 35: 207-22.

Barton, A. D. (2000) 'Accounting for public heritage facilities - assets or liabilities of the government?', Accounting, Auditing \& Accountability Journal 13: 219-36.

Barton, A. D. (2004) 'How to Profit from Defence: A Study in the Misapplication of Business Accounting to the Public Sector in Australia', Financial Accountability \& Management 20: 281-304.

Barton, A. D. (2005) 'Professional Accounting Standards and the Public Sector - a Mismatch', Abacus 41: 138-58.

Barton, A. D. (2009) 'The Use and Abuse of Accounting in the Public Sector Financial Management Reform Program in Australia', Abacus 45: 221-48.

Bradbury, M. and Scott, T. (2015) 'The association between accounting performance and constituent response in political markets', Pacific Accounting Review 27: 394-410 
Broadbent, J. and Guthrie, J. (2008) 'Public sector to public services: 20 years of "contextual” accounting research', Accounting, Auditing \& Accountability Journal 21: 129-69.

Carlin, T. M. (2000) 'Measurement challenges and consequences in the Australian public sector', Australian Accounting Review 10: 63-72.

Carlin, T. M. (2005) 'Debating the Impact of Accrual Accounting and Reporting in the Public Sector', Financial Accountability \& Management 21: 309-36.

Carnegie, G. and Wolnizer, P. (1995) 'The financial value of cultural, heritage and scientific collections: an accounting fiction', Australian Accounting Review 5: 31-47.

Carnegie, G. and P. Wolnizer, 'Unravelling the Rhetoric about the Financial Reporting of Public Collections as Assets', Australian Accounting Review 9: 16-21.

Christiaens, J. and Rommel, J. (2008) 'Accrual Accounting Reforms: Only for Businesslike (parts of) Governments', Financial Accountability \& Management 24: 59-75.

Clark, C. (2002) 'The users of annual reports of government departments', paper presented at the Accountability Symposium, Accounting Association of Australia and New Zealand Conference 6 July.

Coy, D., Dixon, K., Buchanan, J. and Tower, G. (1997) 'Recipients of public sector annual reports: theory and an empirical study compared', British Accounting Review 29: 103-27.

NSW Department of Local Government (NSW) (1993) 'Local Government Act', NSW Government Press.

Ellwood S. and Newberry S. (2007) 'Public sector accrual accounting: institutionalising neo-liberal principles?', Accounting, Auditing \& Accountability Journal 20: 549-73.

Emanuel, D., Wong, J. and Wong, N. (2003), 'Efficient contracting and accounting', Accounting and Finance 43: 149-66.

Financial Reporting Council (2012) 'How the AASB Sets Accounting Standards for the Australian Public Sector'.

Guthrie, J. (1998) 'Application of accrual accounting in the Australian public sector--rhetoric or reality', Financial Accountability \& Management 14: 1-19. 
Holthausen, R. W. (1990) 'Accounting method choice: Opportunistic behavior, efficient contracting, and information perspectives,' Journal of Accounting \& Economics 12: 207-18.

Hooks, J. and Tooley, S. (2007) 'Exercising Professional Judgement in an Era of Sector Neutrality: A Study of Choices Made by New Zealand Reporting Entities', Financial Reporting, Regulation \& Governance 6: 1-33.

Laswad, F., \& Redmayne, N. B. (2015). IPSAS or IFRS as the Framework for Public Sector Financial Reporting? New Zealand Preparers' Perspectives. Australian Accounting Review, 25(2), 175-184.

Lye, J., Perera, H. and Rahman, A. (2005) 'The evolution of accruals-based Crown (government) financial statements in New Zealand', Accounting, Auditing \& Accountability Journal 18: 784-815.

Mack, J. and Ryan, C. (2006) 'Reflections on the theoretical underpinnings of the general-purpose financial reports of Australian government departments', Accounting, Auditing \& Accountability Journal 19: 592-612.

Molland, A., \& Clift, R. (2008). Has the management of infrastructure assets (IAs) improved with the use of the accrual method in local government?. Asian Review of Accounting, 16(2), 97-108.

NSW Local Government Grants Commission (2015) ‘2014-15 Annual Report’.

NSW Office of Local Government (2016) 'Local Government Code of Accounting Practice and Financial Reporting (NSW)'.

NSW Premier and Cabinet, 2013. Local Government Infrastructure Audit.

NSW Treasury Corporation (2013) 'Financial Sustainability of the New South Wales Local Government Sector'.

Pallot, J. (1997) 'Infrastructure accounting for local authorities: technical management and political context', Financial Accountability \& Management 13: 225-42.

Parry, M. (2005) ‘Accrual Accounting for National Governments’, Public Fund Digest 5: 61-7.

Pilcher, R. (2002). Reporting of Roads by NSW Local Councils-Survival of the Fittest. Accounting, Accountability \& Performance, 8(2), 23-41.

Pilcher, R. (2005). Local government financial key performance indicators-not so relevant, reliable and accountable. International Journal of Productivity and Performance Management, 54(5/6), 451-467. 
Pilcher, R. (2006). The smoothing potential of depreciation for local authorities. Journal of Contemporary Issues in Business and Government, 12(2), 67-80.

Pilcher, R. (2009). Deconstructing local government performance and infrastructure measurement. Asian Review of Accounting, 17(2), 163-176.

Pilcher, R. (2011). Implementing IFRS in local government: institutional isomorphism as NPM goes mad?. Local Government Studies, 37(4), 367-389.

Plummer, E., Hutchison, P.D. and Patton, T.K. (2007) 'GASB No. 34's governmental financial reporting model: Evidence on its information relevance', The Accounting Review 82: 205-40.

Priest, A.N., Ng, J. and Dolley, C. (1999) 'Users of local government annual reports: information preferences', Accounting, Accountability and Performance 5: 49-62.

Public Sector Accounting Standards Board, AAS27 (1996), Financial Reporting by Local Governments, ASCPA/ICAA.

Public Sector Accounting Standards Board, AAS27A (1999), Financial Reporting by Local Governments, ASCPA/ICAA.

Public Sector Accounting Standards Board, AAS29 (1996), Financial Reporting by Government Departments, ASCPA/ICAA.

Public Sector Accounting Standards Board, AAS31 (1996), Financial Reporting by Governments, ASCPA/ICAA.

Ryan, C., Guthrie, J. and Day, R. (2007) 'Politics of financial reporting and the consequences for the public sector', Abacus 43: 474-87.

Simpkins, K. (2006) ‘A Review of the Policy of Sector-Neutral Standard-Setting in Australia’, Financial Reporting Council.

Walker, R. G., Clarke, F. L., \& Dean, G. W. (1999). Reporting on the state of infrastructure by local government. Accounting, Auditing \& Accountability Journal, 12(4), 441-459.

Walker, R. G., Dean, G. W., \& Edwards, P. J. (2004). Infrastructure reporting: attitudes of preparers and potential users. Financial Accountability \& Management, 20(4), 351-375. 
Walker, R. G., \& Jones, S. (2012). Reporting on Infrastructure in Australia: practices and management preferences. Abacus, 48(3), 387-413.

Watts, R. L. and Zimmerman, J. L. (1990) 'Positive accounting theory: A ten year perspective', The Accounting Review 65: 13-156. 
TABLES

Table 1: Descriptives (raw variables, not winsorised)

\begin{tabular}{|c|c|c|c|c|c|c|c|}
\hline & mean & minimum & $\begin{array}{c}25^{\text {th }} \\
\text { percentile }\end{array}$ & $\begin{array}{c}50^{\text {th }} \\
\text { percentile }\end{array}$ & $\begin{array}{c}75^{\text {th }} \\
\text { percentile }\end{array}$ & maximum & $\begin{array}{l}\text { standard } \\
\text { deviation }\end{array}$ \\
\hline ARR_total & $611,003,250$ & $24,917,000$ & $245,777,500$ & $419,858,000$ & $692,060,000$ & $4,468,194,000$ & $705,677,664$ \\
\hline CFOnet & $37,150,241$ & $3,296,000$ & $19,116,000$ & $30,083,500$ & $42,390,500$ & $434,544,000$ & $34,859,716$ \\
\hline COMMLANDREVAL & $63,968,312$ & $-2,484,337,920$ & 0 & 0 & 0 & $2,432,965,120$ & $590,187,896$ \\
\hline COMMLANDREVAL_t1 & $48,379,461$ & $-2,484,337,920$ & 0 & 0 & 0 & $2,432,965,120$ & $608,414,148$ \\
\hline COMMLAND_t1 & $430,729,561$ & $4,429,000$ & $39,977,000$ & $129,685,000$ & $391,977,984$ & $3,784,121,088$ & $714,067,878$ \\
\hline COMMLAND_t2 & $436,017,718$ & $4,429,000$ & $37,217,000$ & $132,258,000$ & $415,392,000$ & $3,784,121,088$ & $713,187,881$ \\
\hline$D E P N \_T E$ & 0 & 0 & 0 & 0 & 0 & 1 & 0 \\
\hline EmployeeExpenses & $45,359,724$ & 827,000 & $27,415,500$ & $38,953,000$ & $54,530,000$ & $203,711,000$ & $27,867,706$ \\
\hline EquityTotal & $1,674,261,476$ & $1,700,884$ & $969,436,500$ & $1,404,514,500$ & $2,099,760,000$ & $7,618,770,000$ & $1,092,346,052$ \\
\hline ICAREVAL & $1,391,041,146$ & $-2,484,337,920$ & 101,388 & $36,891,000$ & $118,799,500$ & $251,753,005,056$ & $16,850,225,917$ \\
\hline ICAREVAL_t1 & $741,954,798$ & $-2,484,337,920$ & 89,775 & $34,754,000$ & $119,061,000$ & $185,865,994,240$ & $10,724,736,650$ \\
\hline ICA_t1 & $2,344,339,950$ & $515,388,992$ & $1,444,172,032$ & $2,129,643,008$ & $2,994,659,072$ & $7,687,799,808$ & $1,177,441,233$ \\
\hline ICA_t2 & $2,286,440,819$ & $515,388,992$ & $1,352,210,048$ & $2,076,873,024$ & $2,989,660,928$ & $7,656,348,160$ & $1,148,661,276$ \\
\hline LogTotalAssets & 21.12 & 15.15 & 20.73 & 21.12 & 21.50 & 22.78 & 0.62 \\
\hline MCE & $29,234,172$ & $10,153,000$ & $20,528,500$ & $25,871,500$ & $34,566,000$ & $105,542,000$ & $13,837,454$ \\
\hline$M C P$ & $31,271,131$ & $-26,168,000$ & $20,741,500$ & $28,313,500$ & $37,994,500$ & $118,070,000$ & $15,545,019$ \\
\hline NoEmployees & 570 & 246 & 359 & 503 & 674 & 1,804 & 294 \\
\hline PopPerEmp & 189 & 81 & 124 & 180 & 248 & 356 & 67 \\
\hline Population & 108,664 & 28,431 & 57,394 & 83,317 & 157,914 & 339,328 & 65,263 \\
\hline RevenueBudgeted & $128,626,267$ & $42,687,000$ & $81,814,500$ & $106,685,500$ & $150,011,000$ & $1,004,999,000$ & $88,479,576$ \\
\hline RevenueTotal & $141,151,453$ & $41,860,000$ & $91,456,500$ & $118,075,500$ & $158,598,500$ & $735,552,000$ & $87,304,203$ \\
\hline$S C A$ & $26,586,845$ & 0 & $7,268,736$ & $16,220,000$ & $36,094,720$ & $189,356,944$ & $30,032,144$ \\
\hline OpGrant & $14,067,071$ & $2,019,500$ & $8,204,000$ & $12,679,500$ & $17,817,000$ & $42,521,000$ & $7,308,515$ \\
\hline CapGrant & $22,205,708$ & 5,517 & $6,931,500$ & $12,877,000$ & $23,427,500$ & $687,720,000$ & $43,719,358$ \\
\hline CEO_REMUN & 298,477 & 170,000 & 254,354 & 285,431 & 327,660 & 793,307 & 72,960 \\
\hline MGT_REMUN & 874,054 & 0 & 586,233 & 806,036 & 959,807 & $4,029,939$ & 594,602 \\
\hline
\end{tabular}

Note: Variables are raw, unwinsorised and not standardised by Total Assets. In the remaining tables, except where otherwise stated, variables standardised by Total Assets use the same names with suffix of "_TA". Variables are: ARR_total: balance of total asset revaluation reserve at end of year; CFONET: Net operating cash flows of the current year from the Statement of Cash Flows; COMMLANDREVAL: the net change in any revaluation reserve relating to Community Land; COMMLANDREVAL_t1 : the net change in any revaluation reserve relating to Community Land lagged one period; COMMLAND_t1: Community Land balance at the start of the financial year; COMMLAND_t2: opening Community Land balance lagged one period; DEPN_TE: Depreciation charge as a proportion of total expenses; EmployeeExpenses: Employee Related Expenses from the Income Statement; EquityTotal: Net assets of the LGA; ICAREVAL: the net change in the revaluation reserve relating to Infrastructure Assets; ICAREVAL_t1: the net change in the revaluation reserve relating to Infrastructure Assets lagged one period; ICA_t1: Infrastructure Assets at the start of the financial year; ICA_t2: Infrastructure Assets lagged one period; LogTotalAssets: Total assets of the LGA at the end of the year; MCE: Materials and Contracts Expense for the current financial year, from the Income Statement; $M C P$ : Cash payments related to Materials and Contracts Expense for the current financial year, from the Statement of Cash Flows; NoEmployees: number of full time equivalent employees of LGA at end of the year; Population: Population of LGA in the given year (from Australian Bureau of Statistics); PopPerEmp: Population divided by Number of Employees; RevenueBudgeted: Revenue budgeted by the LGA for the current period; RevenueTotal: Total Revenue of the LGA for the current period; SCA: Total Sum of Contacts Awarded over the reporting threshold for LGAs $(\$ 150,000)$; OpGrant: Total Operating Grants received by the LGA during the year; CapGrant: Total Capital Grants received by the LGA during the year; CEO_REMUN: Total annual remuneration of the chief executive of the LGA; MGT_REMUN: Total annual remuneration of management of the LGA. 
Table 2: Correlation Matrix

\begin{tabular}{|c|c|c|c|c|c|c|c|c|c|c|c|c|c|c|c|c|c|c|c|c|c|c|c|c|c|}
\hline & & 1 & 2 & 3 & 4 & 5 & 6 & 7 & 8 & 9 & 10 & 11 & 13 & 14 & 15 & 16 & 17 & 18 & 19 & 20 & 21 & 22 & 23 & 24 & 25 \\
\hline 1 & SCA_TA & 1.00 & & & & & & & & & & & & & & & & & & & & & & & \\
\hline 2 & MCE_TA & $\begin{array}{l}1.00 \\
0.00\end{array}$ & 1.00 & & & & & & & & & & & & & & & & & & & & & & \\
\hline 3 & $M C P_{-} T A$ & $\begin{array}{l}1.00 \\
0.00\end{array}$ & $\begin{array}{l}1.00 \\
0.00\end{array}$ & 1.00 & & & & & & & & & & & & & & & & & & & & & \\
\hline 4 & CEO_REMUN_TA & 0.01 & 0.60 & 0.47 & 1.00 & & & & & & & & & & & & & & & & & & & & \\
\hline & & -0.92 & 0.00 & 0.00 & & & & & & & & & & & & & & & & & & & & & \\
\hline 5 & MGT_REMUN_TA & 1.00 & 1.00 & 1.00 & 0.55 & 1.00 & & & & & & & & & & & & & & & & & & & \\
\hline & & 0.00 & 0.00 & 0.00 & 0.00 & & & & & & & & & & & & & & & & & & & & \\
\hline 6 & COMMLANDREVAL_TA & 1.00 & 1.00 & 1.00 & -0.07 & 1.00 & 1.00 & & & & & & & & & & & & & & & & & & \\
\hline & & 0.00 & 0.00 & 0.00 & -0.63 & 0.00 & & & & & & & & & & & & & & & & & & & \\
\hline 7 & COMMLANDREVAL_t1_TA & -0.07 & -0.15 & -0.16 & 0.07 & 0.20 & -0.03 & 1.00 & & & & & & & & & & & & & & & & & \\
\hline & & -0.66 & -0.33 & -0.29 & -0.66 & -0.17 & -0.87 & & & & & & & & & & & & & & & & & & \\
\hline 8 & ICAREVAL_TA & 0.98 & 0.99 & 0.99 & -0.06 & 0.99 & 1.00 & -0.02 & 1.00 & & & & & & & & & & & & & & & & \\
\hline & & 0.00 & 0.00 & 0.00 & -0.28 & 0.00 & 0.00 & -0.89 & & & & & & & & & & & & & & & & & \\
\hline 9 & ICAREVAL_t1_TA & -0.02 & -0.05 & -0.05 & -0.04 & -0.02 & -0.14 & 0.95 & 0.04 & 1.00 & & & & & & & & & & & & & & & \\
\hline & & -0.77 & -0.42 & -0.42 & -0.54 & -0.67 & -0.36 & 0.00 & -0.53 & & & & & & & & & & & & & & & & \\
\hline 10 & COMMLAND_t1_TA & -0.04 & -0.28 & -0.24 & -0.13 & -0.02 & -0.63 & 0.18 & -0.03 & 0.01 & 1.00 & & & & & & & & & & & & & & \\
\hline & & -0.49 & 0.00 & 0.00 & -0.03 & -0.71 & 0.00 & -0.23 & -0.67 & -0.88 & & & & & & & & & & & & & & & \\
\hline 11 & COMMLAND_t2_TA & 0.05 & -0.14 & -0.15 & -0.02 & 0.01 & -0.55 & -0.54 & -0.03 & 0.00 & 0.86 & 1.00 & & & & & & & & & & & & & \\
\hline & & -0.46 & -0.02 & -0.02 & -0.72 & -0.91 & 0.00 & 0.00 & -0.66 & -0.99 & 0.00 & & & & & & & & & & & & & & \\
\hline 13 & ICA_t1_TA & -0.02 & 0.31 & 0.29 & 0.21 & 0.00 & -0.69 & -0.09 & -0.02 & 0.04 & -0.12 & -0.01 & 1.00 & & & & & & & & & & & & \\
\hline & & -0.78 & 0.00 & 0.00 & 0.00 & -0.96 & 0.00 & -0.56 & -0.72 & -0.47 & -0.04 & -0.84 & & & & & & & & & & & & & \\
\hline 14 & ICA_t2_TA & 0.03 & 0.32 & 0.33 & 0.22 & 0.03 & -0.43 & -0.60 & -0.01 & 0.02 & -0.03 & 0.19 & 0.70 & 1.00 & & & & & & & & & & & \\
\hline & & -0.65 & 0.00 & 0.00 & 0.00 & -0.63 & -0.01 & 0.00 & -0.87 & -0.76 & -0.67 & 0.00 & 0.00 & & & & & & & & & & & & \\
\hline 15 & ARR_total_TA & 1.00 & 1.00 & 1.00 & -0.14 & 1.00 & 1.00 & 0.12 & 0.99 & 0.05 & -0.25 & -0.30 & 0.09 & -0.04 & 1.00 & & & & & & & & & & \\
\hline & & 0.00 & 0.00 & 0.00 & -0.01 & 0.00 & 0.00 & -0.44 & 0.00 & -0.39 & 0.00 & 0.00 & -0.11 & -0.57 & & & & & & & & & & & \\
\hline 16 & CFOnet_TA & 0.99 & 1.00 & 1.00 & 0.12 & 1.00 & 1.00 & -0.31 & 0.99 & 0.03 & -0.19 & -0.11 & 0.16 & 0.16 & 1.00 & 1.00 & & & & & & & & & \\
\hline & & 0.00 & 0.00 & 0.00 & -0.02 & 0.00 & 0.00 & -0.03 & 0.00 & -0.62 & 0.00 & -0.08 & -0.01 & -0.01 & 0.00 & & & & & & & & & & \\
\hline 17 & Depn_tA & 1.00 & 1.00 & 1.00 & 0.17 & 1.00 & 1.00 & -0.22 & 0.99 & 0.05 & -0.46 & -0.33 & 0.44 & 0.32 & 1.00 & 1.00 & 1.00 & & & & & & & & \\
\hline & & 0.00 & 0.00 & 0.00 & 0.00 & 0.00 & 0.00 & -0.15 & 0.00 & -0.36 & 0.00 & 0.00 & 0.00 & 0.00 & 0.00 & 0.00 & & & & & & & & & \\
\hline 18 & EmployeeExpenses_TA & 1.00 & 1.00 & 1.00 & 0.50 & 1.00 & 1.00 & -0.03 & 0.99 & 0.03 & -0.12 & 0.00 & 0.06 & 0.14 & 1.00 & 1.00 & 1.00 & 1.00 & & & & & & & \\
\hline & & 0.00 & 0.00 & 0.00 & 0.00 & 0.00 & 0.00 & -0.87 & 0.00 & -0.66 & -0.03 & -0.98 & -0.28 & -0.03 & 0.00 & 0.00 & 0.00 & & & & & & & & \\
\hline 19 & EquityTotal_TA & -0.37 & -0.37 & -0.37 & 0.01 & -0.37 & -0.98 & 0.09 & -0.37 & -0.02 & 0.45 & 0.39 & -0.28 & -0.16 & -0.37 & -0.37 & -0.37 & -0.37 & 1.00 & & & & & & \\
\hline & & 0.00 & 0.00 & 0.00 & -0.84 & 0.00 & 0.00 & -0.55 & 0.00 & -0.75 & 0.00 & 0.00 & 0.00 & -0.01 & 0.00 & 0.00 & 0.00 & 0.00 & & & & & & & \\
\hline 20 & RevenueBudgeted_TA & 1.00 & 1.00 & 1.00 & 0.31 & 1.00 & 1.00 & -0.09 & 0.99 & 0.00 & -0.18 & -0.11 & 0.09 & 0.10 & 1.00 & 1.00 & 1.00 & 1.00 & -0.37 & 1.00 & & & & & \\
\hline & & 0.00 & 0.00 & 0.00 & 0.00 & 0.00 & 0.00 & -0.55 & 0.00 & -0.99 & 0.00 & -0.08 & -0.10 & -0.11 & 0.00 & 0.00 & 0.00 & 0.00 & 0.00 & & & & & & \\
\hline 21 & RevenueTotal_TA & 1.00 & 1.00 & 1.00 & 0.55 & 1.00 & 1.00 & -0.14 & 0.99 & 0.02 & -0.30 & -0.17 & 0.19 & 0.20 & 1.00 & 1.00 & 1.00 & 1.00 & -0.37 & 1.00 & 1.00 & & & & \\
\hline & & 0.00 & 0.00 & 0.00 & 0.00 & 0.00 & 0.00 & -0.36 & 0.00 & -0.74 & 0.00 & -0.01 & 0.00 & 0.00 & 0.00 & 0.00 & 0.00 & 0.00 & 0.00 & 0.00 & & & & & \\
\hline 22 & OpGrant_TA & 1.00 & 1.00 & 1.00 & 0.41 & 1.00 & 1.00 & -0.18 & 0.99 & 0.04 & -0.50 & -0.42 & 0.26 & 0.13 & 1.00 & 1.00 & 1.00 & 1.00 & -0.37 & 1.00 & 1.00 & 1.00 & & & \\
\hline & & 0.00 & 0.00 & 0.00 & 0.00 & 0.00 & 0.00 & -0.22 & 0.00 & -0.54 & 0.00 & 0.00 & 0.00 & -0.03 & 0.00 & 0.00 & 0.00 & 0.00 & 0.00 & 0.00 & 0.00 & & & & \\
\hline 23 & CapGrant_TA & 0.90 & 0.90 & 0.90 & 0.11 & 0.90 & 0.90 & -0.02 & 0.89 & 0.00 & -0.05 & -0.04 & -0.09 & -0.09 & 0.90 & 0.90 & 0.90 & 0.90 & -0.33 & 0.90 & 0.90 & 0.90 & 1.00 & & \\
\hline & & 0.00 & 0.00 & 0.00 & -0.04 & 0.00 & 0.00 & -0.89 & 0.00 & -0.98 & -0.38 & -0.51 & -0.13 & -0.15 & 0.00 & 0.00 & 0.00 & 0.00 & 0.00 & 0.00 & 0.00 & 0.00 & & & \\
\hline 24 & NoEmployees_TA & 1.00 & 1.00 & 1.00 & 0.58 & 1.00 & 1.00 & -0.07 & 0.99 & 0.03 & -0.22 & -0.10 & 0.14 & 0.17 & 1.00 & 1.00 & 1.00 & 1.00 & -0.37 & 1.00 & 1.00 & 1.00 & 0.90 & 1.00 & \\
\hline & & 0.00 & 0.00 & 0.00 & 0.00 & 0.00 & 0.00 & -0.65 & 0.00 & -0.64 & 0.00 & -0.10 & -0.02 & -0.01 & 0.00 & 0.00 & 0.00 & 0.00 & 0.00 & 0.00 & 0.00 & 0.00 & 0.00 & & \\
\hline 25 & population_TA & 1.00 & 1.00 & 1.00 & 0.40 & 1.00 & 1.00 & -0.21 & 0.99 & 0.04 & 0.02 & 0.13 & 0.00 & 0.11 & 1.00 & 1.00 & 1.00 & 1.00 & -0.37 & 1.00 & 1.00 & 1.00 & 0.90 & 1.00 & 1.00 \\
\hline & & 0.00 & 0.00 & 0.00 & 0.00 & 0.00 & 0.00 & -0.16 & 0.00 & -0.46 & -0.67 & -0.04 & -0.94 & -0.08 & 0.00 & 0.00 & 0.00 & 0.00 & 0.00 & 0.00 & 0.00 & 0.00 & 0.00 & 0.00 & \\
\hline
\end{tabular}

Note: $p$ values are in italics $\mathrm{p}<0.1$. Variables are as described in Table 1, excepting that all standardised by Total Assets in this Table (hence the " TA" suffix). 
Table 3: Determinants of Contracts (Contracts over threshold, Materials and Contracts Expense)

$\begin{array}{llll}\text { (1) } & \text { (2) } & \text { (3) } & \text { (4) }\end{array}$

\begin{tabular}{|c|c|c|c|c|}
\hline & SCA_TA & MCE_TA & $S C A \_T A$ & MCE_TA \\
\hline LogTotalAssets & $\begin{array}{l}-0.0061 \\
(0.651)\end{array}$ & $\begin{array}{c}-0.0167^{* * *} \\
(0.000)\end{array}$ & $\begin{array}{l}-0.0056 \\
(0.319)\end{array}$ & $\begin{array}{c}-0.0090 * * * \\
(0.000)\end{array}$ \\
\hline COMMLANDREVAL_TA & $\begin{array}{l}-0.0239 \\
(0.592)\end{array}$ & $\begin{array}{l}0.0005 \\
(0.931)\end{array}$ & & \\
\hline ICAREVAL_TA & $\begin{array}{l}0.0101 \\
(0.794)\end{array}$ & $\begin{array}{l}-0.0017 \\
(0.721)\end{array}$ & $\begin{array}{l}0.0001 \\
(0.455)\end{array}$ & $\begin{array}{c}0.0000^{*} \\
(0.050)\end{array}$ \\
\hline COMMLAND_t1_TA & $\begin{array}{l}-0.0120 \\
(0.382)\end{array}$ & $\begin{array}{c}-0.0047^{* * *} \\
(0.006)\end{array}$ & & \\
\hline$I C A \_t 1 \_T A$ & $\begin{array}{l}0.0060 \\
(0.462)\end{array}$ & $\begin{array}{c}0.0024^{* *} \\
(0.018)\end{array}$ & $\begin{array}{l}0.0001 \\
(0.980)\end{array}$ & $\begin{array}{l}0.0005 \\
(0.327)\end{array}$ \\
\hline CFOnet_TA & $\begin{array}{l}-0.2675 \\
(0.455)\end{array}$ & $\begin{array}{l}-0.0173 \\
(0.700)\end{array}$ & $\begin{array}{r}-0.0000 \\
(1.000)\end{array}$ & $\begin{array}{l}-0.0063 \\
(0.536)\end{array}$ \\
\hline EmployeeExpenses_TA & $\begin{array}{l}-0.4392 \\
(0.294)\end{array}$ & $\begin{array}{c}-0.2073^{* * *} \\
(0.000)\end{array}$ & $\begin{array}{l}0.0901 \\
(0.641)\end{array}$ & $\begin{array}{c}0.0828^{*} \\
(0.076)\end{array}$ \\
\hline EquityTotal_TA & $\begin{array}{l}0.1034 \\
(0.767)\end{array}$ & $\begin{array}{c}0.0823 * \\
(0.060)\end{array}$ & $\begin{array}{r}-0.0134 \\
(0.773)\end{array}$ & $\begin{array}{l}0.0069 \\
(0.593)\end{array}$ \\
\hline RevenueBudgeted_TA & $\begin{array}{l}0.0596 \\
(0.798)\end{array}$ & $\begin{array}{c}0.1181^{* * *} \\
(0.000)\end{array}$ & $\begin{array}{l}0.0132 \\
(0.423)\end{array}$ & $\begin{array}{l}-0.0043 \\
(0.134)\end{array}$ \\
\hline RevenueTotal_TA & $\begin{array}{l}-0.0086 \\
(0.948)\end{array}$ & $\begin{array}{c}-0.0361^{* *} \\
(0.029)\end{array}$ & $\begin{array}{r}-0.0449 \\
(0.485)\end{array}$ & $\begin{array}{c}0.0824^{* * *} \\
(0.000)\end{array}$ \\
\hline PopPerEmp & $\begin{array}{l}0.0000 \\
(0.963)\end{array}$ & $\begin{array}{r}-0.0000 \\
(0.285)\end{array}$ & $\begin{array}{c}0.0001^{*} \\
(0.073)\end{array}$ & $\begin{array}{c}0.0000^{* * *} \\
(0.008)\end{array}$ \\
\hline population & $\begin{array}{l}0.0000 \\
(0.890)\end{array}$ & $\begin{array}{c}0.0000 * * * \\
(0.000)\end{array}$ & $\begin{array}{r}-0.0000 \\
(0.167)\end{array}$ & $\begin{array}{c}-0.0000 * * \\
(0.019)\end{array}$ \\
\hline number of FTE employees EOY & $\begin{array}{l}0.0000 \\
(0.533)\end{array}$ & $\begin{array}{c}0.0000 * * \\
(0.014)\end{array}$ & $\begin{array}{l}0.0000 \\
(0.102)\end{array}$ & $\begin{array}{c}0.0000 * * * \\
(0.010)\end{array}$ \\
\hline Constant & $\begin{array}{l}0.0343 \\
(0.945)\end{array}$ & $\begin{array}{c}0.2774 * * * \\
(0.000)\end{array}$ & $\begin{array}{l}0.1272 \\
(0.316)\end{array}$ & $\begin{array}{c}0.1832^{* * *} \\
(0.000)\end{array}$ \\
\hline R-squared & 0.1801 & 0.9760 & 0.0533 & 0.5320 \\
\hline Observations & 45 & 45 & 300 & 301 \\
\hline Number of LGAcode & 9 & 9 & 43 & 43 \\
\hline
\end{tabular}

Note: $p$ values in parentheses, significance marked as follows: ${ }^{* * *} p<0.01,{ }^{* *} p<0.05,{ }^{*} p<0.1$. Variables are as described in Table 1. Variables described in Table 1 which have been standardised by Total Assets are renamed with a suffix of "_TA". 
Table 4: Determinants of Contracts (Contracts over threshold, Materials and Contracts Expense)

\begin{tabular}{|c|c|c|c|c|}
\hline & $\begin{array}{c}(1) \\
S C A_{-} T A\end{array}$ & $\begin{array}{c}(2) \\
M C E_{-} T A\end{array}$ & $\begin{array}{c}(3) \\
S C A \_T A\end{array}$ & $\begin{array}{c}\text { (4) } \\
M C E_{-} T A\end{array}$ \\
\hline LogTotalAssets & $\begin{array}{c}-0.0123 \\
(0.744)\end{array}$ & $\begin{array}{c}-0.0097 * * * \\
(0.002)\end{array}$ & $\begin{array}{c}-0.0052 \\
(0.363)\end{array}$ & $\begin{array}{c}-0.0069 * * * \\
(0.000)\end{array}$ \\
\hline COMMLANDREVAL_TA & $\begin{array}{l}-0.0070 \\
(0.948)\end{array}$ & $\begin{array}{r}-0.0106 \\
(0.243)\end{array}$ & & \\
\hline COMMLANDREVAL_t1_TA & $\begin{array}{l}0.0128 \\
(0.858)\end{array}$ & $\begin{array}{c}-0.0154^{* *} \\
(0.011)\end{array}$ & & \\
\hline ICAREVAL_TA & $\begin{array}{l}0.0020 \\
(0.983)\end{array}$ & $\begin{array}{l}0.0092 \\
(0.243)\end{array}$ & $\begin{array}{l}0.0001 \\
(0.313)\end{array}$ & $\begin{array}{l}0.0000 \\
(0.189)\end{array}$ \\
\hline ICAREVAL_t1_TA & $\begin{array}{c}-0.0108 \\
(0.857)\end{array}$ & $\begin{array}{c}0.0130 * * * \\
(0.010)\end{array}$ & $\begin{array}{c}-0.0000 \\
(0.774)\end{array}$ & $\begin{array}{c}-0.0000 \\
(0.214)\end{array}$ \\
\hline COMMLAND_t2_TA & $\begin{array}{l}0.0021 \\
(0.947)\end{array}$ & $\begin{array}{c}-0.0056^{* *} \\
(0.036)\end{array}$ & & \\
\hline ICA_t2_TA & $\begin{array}{l}0.0046 \\
(0.839)\end{array}$ & $\begin{array}{c}0.0034^{*} \\
(0.073)\end{array}$ & $\begin{array}{l}0.0016 \\
(0.463)\end{array}$ & $\begin{array}{l}0.0005 \\
(0.230)\end{array}$ \\
\hline CFOnet_TA & $\begin{array}{l}-0.8483 \\
(0.191)\end{array}$ & $\begin{array}{c}-0.1324^{* *} \\
(0.015)\end{array}$ & $\begin{array}{r}-0.0406 \\
(0.430)\end{array}$ & $\begin{array}{l}-0.0042 \\
(0.668)\end{array}$ \\
\hline EmployeeExpenses_TA & $\begin{array}{c}-1.9622 \\
(0.381)\end{array}$ & $\begin{array}{c}-0.0518 \\
(0.783)\end{array}$ & $\begin{array}{l}0.1968 \\
(0.293)\end{array}$ & $\begin{array}{l}0.0580 \\
(0.244)\end{array}$ \\
\hline EquityTotal_TA & $\begin{array}{l}0.1313 \\
(0.806)\end{array}$ & $\begin{array}{c}0.0946 * * \\
(0.035)\end{array}$ & $\begin{array}{r}-0.0077 \\
(0.874)\end{array}$ & $\begin{array}{c}-0.0170 \\
(0.272)\end{array}$ \\
\hline RevenueBudgeted_TA & $\begin{array}{l}0.3523 \\
(0.551)\end{array}$ & $\begin{array}{c}0.1890 * * * \\
(0.000)\end{array}$ & $\begin{array}{l}0.0141 \\
(0.325)\end{array}$ & $\begin{array}{c}-0.0038 \\
(0.153)\end{array}$ \\
\hline RevenueTotal_TA & $\begin{array}{l}0.1911 \\
(0.510)\end{array}$ & $\begin{array}{c}-0.0159 \\
(0.515)\end{array}$ & $\begin{array}{c}-0.0604 \\
(0.329)\end{array}$ & $\begin{array}{c}0.0791^{* * *} \\
(0.000)\end{array}$ \\
\hline PopPerEmp & $\begin{array}{l}0.0001 \\
(0.602)\end{array}$ & $\begin{array}{l}0.0000 \\
(0.189)\end{array}$ & $\begin{array}{c}0.0001 * \\
(0.052)\end{array}$ & $\begin{array}{l}0.0000 * \\
(0.054)\end{array}$ \\
\hline population & $\begin{array}{l}0.0000 \\
(0.993)\end{array}$ & $\begin{array}{c}0.0000 * * * \\
(0.002)\end{array}$ & $\begin{array}{c}-0.0000 \\
(0.131)\end{array}$ & $\begin{array}{c}-0.0000^{*} \\
(0.087)\end{array}$ \\
\hline number of FTE employees EOY & $\begin{array}{l}0.0000 \\
(0.398)\end{array}$ & $\begin{array}{c}0.0000 * * \\
(0.037)\end{array}$ & $\begin{array}{c}0.0000^{*} \\
(0.093)\end{array}$ & $\begin{array}{c}0.0000^{*} \\
(0.068)\end{array}$ \\
\hline Constant & $\begin{array}{l}0.0994 \\
(0.929)\end{array}$ & $\begin{array}{l}0.0990 \\
(0.290)\end{array}$ & $\begin{array}{l}0.1090 \\
(0.404)\end{array}$ & $\begin{array}{c}0.1654^{* * *} \\
(0.000)\end{array}$ \\
\hline $\begin{array}{l}\text { R-squared } \\
\text { Observations } \\
\text { Number of LGAcode }\end{array}$ & $\begin{array}{c}0.2632 \\
36 \\
6\end{array}$ & $\begin{array}{c}0.9876 \\
36 \\
6\end{array}$ & $\begin{array}{c}0.0829 \\
257 \\
43\end{array}$ & $\begin{array}{c}0.5256 \\
258 \\
43\end{array}$ \\
\hline
\end{tabular}

Number of LGAcode

Note: $p$ values in parentheses, significance marked as follows: ${ }^{* * *} p<0.01,{ }^{* *} p<0.05,{ }^{*} p<0.1$. Variables are as described in Table 1. Variables described in Table 1 which have been standardised by Total Assets are renamed with a suffix of "_TA". 
Table 5: Determinants of CEO \& Management remuneration
(1)
(2)
(3)
(4)

\begin{tabular}{c|ccc} 
CEO_REMUN_TA & MGT_REMUN_TA & CEO_REMUN_TA & MGT_REMUN_TA \\
\hline 0.0000 & -0.0002 & $-0.0001^{* * *}$ & -0.0001
\end{tabular}

\begin{tabular}{l|c|c|c|c}
\hline LogTotalAssets & 0.0000 & -0.0002 & $-0.0001^{* * *}$ & -0.0001 \\
& $(0.897)$ & $(0.488)$ & $(0.000)$ & $(0.180)$ \\
COMMLANDREVAL_TA & -0.0001 & 0.0001 & & \\
& $(0.699)$ & $(0.913)$ & & \\
ICAREVAL_TA & 0.0000 & -0.0004 & 0.0000 & -0.0000 \\
COMMLAND_t1_TA & $(0.793)$ & $(0.596)$ & $(0.783)$ & $(0.770)$ \\
& 0.0000 & -0.0002 & & \\
ICA_t1_TA & $(0.955)$ & $(0.370)$ & & \\
& 0.0000 & -0.0000 & $0.0000^{*}$ & 0.0000 \\
CFOnet_TA & $(0.431)$ & $(0.860)$ & $(0.087)$ & $(0.813)$ \\
& -0.0019 & -0.0104 & 0.0000 & -0.0006 \\
EmployeeExpenses_TA & $(0.210)$ & $(0.124)$ & $(0.977)$ & $(0.475)$ \\
& -0.0013 & -0.0116 & $0.0014^{* *}$ & 0.0043 \\
EquityTotaI_TA & $(0.473)$ & $(0.144)$ & $(0.019)$ & $(0.232)$ \\
& -0.0011 & 0.0010 & $0.0002^{*}$ & 0.0004 \\
RevenueBudgeted_TA & $(0.464)$ & $(0.880)$ & $(0.082)$ & $(0.672)$ \\
& $0.0022^{* *}$ & $0.0080^{*}$ & 0.0000 & -0.0002 \\
RevenueTotaI_TA & $(0.024)$ & $(0.069)$ & $(0.526)$ & $(0.322)$ \\
& 0.0003 & 0.0006 & $0.0004^{* *}$ & $0.0032^{* * *}$ \\
PopPerEmp & $(0.529)$ & $(0.814)$ & $(0.027)$ & $(0.003)$ \\
& 0.0000 & -0.0000 & $0.0000^{* * *}$ & 0.0000 \\
population & $(0.367)$ & $(0.685)$ & $(0.001)$ & $(0.649)$ \\
& -0.0000 & 0.0000 & $-0.0000^{* * *}$ & -0.0000 \\
number of FTE employees EOY & $(0.250)$ & $(0.117)$ & $(0.002)$ & $(0.680)$ \\
& -0.0000 & -0.0000 & $0.0000^{* *}$ & 0.0000 \\
Constant & $(0.810)$ & $(0.777)$ & $(0.041)$ & $(0.909)$ \\
& 0.0009 & 0.0031 & $0.0025^{* * *}$ & 0.0025 \\
R-squared & $(0.659)$ & $(0.742)$ & $(0.000)$ & $(0.229)$ \\
Observations & & & & \\
Number of LGAcode & 0.8622 & 0.5910 & 0.7983 & 0.2697 \\
Not & 41 & 42 & 294 & 301 \\
& 6 & 6 & 43 & 43 \\
\hline
\end{tabular}

Note: $p$ values in parentheses, significance marked as follows: ${ }^{* *} p<0.01,{ }^{* *} p<0.05,{ }^{*} p<0.1$. Variables are as described in Table 1. Variables described in Table 1 which have been standardised by Total Assets are renamed with a suffix of "_TA". 
Table 6: Determinants of CEO \& MGT remuneration including lagged revaluations

\begin{tabular}{|c|c|c|c|c|}
\hline & $\begin{array}{c}(1) \\
\text { CEO_REMUN_TA }\end{array}$ & $\begin{array}{c}\text { (2) } \\
M G T_{-} R E M U N_{-} T A\end{array}$ & $\begin{array}{c}\text { (3) } \\
\text { CEO_REMUN_TA }\end{array}$ & $\begin{array}{c}(4) \\
M G T \_R E M U N \_T A\end{array}$ \\
\hline LogTotalAssets & $\begin{array}{l}0.0000 \\
(0.825)\end{array}$ & $\begin{array}{l}-0.0003 \\
(0.341)\end{array}$ & $\begin{array}{c}-0.0001^{* * *} \\
(0.000)\end{array}$ & $\begin{array}{c}-0.0002 \\
(0.150)\end{array}$ \\
\hline COMMLANDREVAL_TA & $\begin{array}{l}-0.0005 \\
(0.194)\end{array}$ & $\begin{array}{l}-0.0011 \\
(0.192)\end{array}$ & & \\
\hline COMMLANDREVAL_t1_TA & $\begin{array}{l}-0.0003 \\
(0.305)\end{array}$ & $\begin{array}{c}-0.0010^{*} \\
(0.065)\end{array}$ & & \\
\hline ICAREVAL_TA & $\begin{array}{l}0.0004 \\
(0.219)\end{array}$ & $\begin{array}{l}0.0007 \\
(0.369)\end{array}$ & $\begin{array}{l}0.0000 \\
(0.954)\end{array}$ & $\begin{array}{r}-0.0000 \\
(0.784)\end{array}$ \\
\hline ICAREVAL_t1_TA & $\begin{array}{l}0.0003 \\
(0.216)\end{array}$ & $\begin{array}{l}0.0007 \\
(0.128)\end{array}$ & $\begin{array}{r}-0.0000 \\
(0.747)\end{array}$ & $\begin{array}{l}0.0000 \\
(0.935)\end{array}$ \\
\hline COMMLAND_t2_TA & $\begin{array}{l}-0.0002 \\
(0.163)\end{array}$ & $\begin{array}{c}-0.0009 * * * \\
(0.000)\end{array}$ & & \\
\hline$I C A \_t 2 \_T A$ & $\begin{array}{l}0.0002^{*} \\
(0.084)\end{array}$ & $\begin{array}{l}0.0003 \\
(0.122)\end{array}$ & $\begin{array}{l}0.0000 * \\
(0.071)\end{array}$ & $\begin{array}{l}-0.0000 \\
(0.578)\end{array}$ \\
\hline CFOnet_TA & $\begin{array}{l}0.0008 \\
(0.750)\end{array}$ & $\begin{array}{l}0.0041 \\
(0.413)\end{array}$ & $\begin{array}{l}0.0000 \\
(0.954)\end{array}$ & $\begin{array}{l}-0.0009 \\
(0.253)\end{array}$ \\
\hline EmployeeExpenses_TA & $\begin{array}{l}0.0081 \\
(0.348)\end{array}$ & $\begin{array}{l}0.0180 \\
(0.304)\end{array}$ & $\begin{array}{l}0.0004 \\
(0.439)\end{array}$ & $\begin{array}{l}0.0012 \\
(0.750)\end{array}$ \\
\hline EquityTotal_TA & $\begin{array}{r}-0.0002 \\
(0.906)\end{array}$ & $\begin{array}{l}-0.0064 \\
(0.123)\end{array}$ & $\begin{array}{l}0.0003^{*} \\
(0.072)\end{array}$ & $\begin{array}{l}0.0007 \\
(0.529)\end{array}$ \\
\hline RevenueBudgeted_TA & $\begin{array}{l}-0.0013 \\
(0.557)\end{array}$ & $\begin{array}{r}-0.0047 \\
(0.304)\end{array}$ & $\begin{array}{l}0.0000 \\
(0.487)\end{array}$ & $\begin{array}{l}-0.0002 \\
(0.309)\end{array}$ \\
\hline RevenueTotal_TA & $\begin{array}{l}-0.0005 \\
(0.655)\end{array}$ & $\begin{array}{l}-0.0037 \\
(0.101)\end{array}$ & $\begin{array}{c}0.0004^{* *} \\
(0.012)\end{array}$ & $\begin{array}{c}0.0033 * * * \\
(0.002)\end{array}$ \\
\hline PopPerEmp & $\begin{array}{r}-0.0000 \\
(0.390)\end{array}$ & $\begin{array}{l}-0.0000 \\
(0.241)\end{array}$ & $\begin{array}{c}0.0000^{* * *} \\
(0.001)\end{array}$ & $\begin{array}{l}0.0000 \\
(0.879)\end{array}$ \\
\hline population & $\begin{array}{l}0.0000 \\
(0.852)\end{array}$ & $\begin{array}{l}0.0000^{*} \\
(0.070)\end{array}$ & $\begin{array}{c}-0.0000 * * * \\
(0.003)\end{array}$ & $\begin{array}{l}-0.0000 \\
(0.907)\end{array}$ \\
\hline number of FTE employees EOY & $\begin{array}{l}-0.0000 \\
(0.280)\end{array}$ & $\begin{array}{r}-0.0000 \\
(0.741)\end{array}$ & $\begin{array}{c}0.0000 * * \\
(0.020)\end{array}$ & $\begin{array}{l}0.0000 \\
(0.937)\end{array}$ \\
\hline Constant & $\begin{array}{l}-0.0001 \\
(0.973)\end{array}$ & $\begin{array}{l}0.0130 \\
(0.134)\end{array}$ & $\begin{array}{c}0.0026 * * * \\
(0.000)\end{array}$ & $\begin{array}{l}0.0029 \\
(0.230)\end{array}$ \\
\hline R-squared & 0.8339 & 0.8722 & 0.8151 & 0.2328 \\
\hline Observations & 36 & 36 & 254 & 258 \\
\hline Number of LGAcode & 6 & 6 & 43 & 43 \\
\hline
\end{tabular}

Note: $p$ values in parentheses, significance marked as follows: ${ }^{* * *} p<0.01,{ }^{* *} p<0.05,{ }^{*} p<0.1$. Variables are as described in Table 1. Variables described in Table 1 which have been standardised by Total Assets are renamed with a suffix of "_TA". 
Table 7: Determinants of Operating and Capital Grants

(1) (2)

(3)

(4)

OpGrants TA

CapGrants TA

OpGrants $T A$

LogTotalAssets

$-0.0111^{* *}$

0.1996

$(0.000)$

0.0026

$(0.680)$

$-0.0018$

(0.761)

ICAREVAL_t1_TA

COMMLAND_t2_TA

ICA_t2_TA

CFOnet_TA

EmployeeExpenses_TA

EquityTotal_TA

$-0.0028^{*}$

(0.050)

$0.0032 * *$

(0.016)

0.0597

(0.175)

$-2.1356 * * *$

(0.000)

$2.1734^{* * *}$

(0.000)

$-0.0061^{* *}$

CapGrants TA

RevenueBudgeted_TA

RevenueTotal_TA

(0.168)

$(0.000)$

$(0.000)$

$(0.674)$

0.0120

(0.783)

$-0.0665^{*}$

(0.099)

$-0.0072$

(0.647)

PopPerEmp

$-0.0001^{* * *}$

(0.000)

population

$0.0000 * * *$

(0.000)

$-0.0000$

number of FTE employees

$(0.482)$

$0.2433 * * *$

$-2.7487$

0.0266

$(0.801)$

0.0868

(0.362)

$-5.2147^{*}$

(0.097)

$-1.6842$

(0.652)

$-2.0647$

(0.512)

3.8952

(0.183)

1.2968

(0.257)

0.0013

(0.221)

$-0.0000$

(0.116)

0.0001

$(0.000)$

(0.573)

0.0000

0.0001

(0.939) $\quad(0.787)$

0.0000

0.0001

(0.965)

(0.864)

Constant

0.9222

39

R-squared

Observations

Number of LGAcode

9

0.7610

39

Note: $p$ values in parentheses, significance marked as follows: $* * * p<0.01, * * p<0.05, * p<0.1$. Variables are as described in

Table 1. Variables described in Table 1 which have been standardised by Total Assets are renamed with a suffix of "_TA". 
Table 8: Determinants of Depreciation and Asset Revaluation Reserve

\begin{tabular}{|c|c|c|c|}
\hline Panel A - Contemporaneous & $\begin{array}{c}(1) \\
D E P N \_T E\end{array}$ & $\begin{array}{c}(2) \\
A R R \_T A\end{array}$ & $\begin{array}{c}(3) \\
S C A \_T A\end{array}$ \\
\hline LogTotalAssets & $\begin{array}{c}0.0362 * * * \\
(0.001)\end{array}$ & $\begin{array}{c}1.2976 * * * \\
(0.000)\end{array}$ & $\begin{array}{c}-0.0090^{*} \\
(0.061)\end{array}$ \\
\hline$S C A_{-} T A$ & $\begin{array}{l}0.2621 \\
(0.219)\end{array}$ & $\begin{array}{c}1.5821^{* *} \\
(0.018)\end{array}$ & \\
\hline$D E P N \_T E$ & & & $\begin{array}{l}0.0162 \\
(0.235)\end{array}$ \\
\hline$A R R_{-} T A$ & & & $\begin{array}{l}0.0052 \\
(0.125)\end{array}$ \\
\hline CFOnet_TA & $\begin{array}{l}0.0990 \\
(0.661)\end{array}$ & $\begin{array}{l}1.2896^{*} \\
(0.069)\end{array}$ & $\begin{array}{l}0.0049 \\
(0.933)\end{array}$ \\
\hline EmployeeExpenses_TA & $\begin{array}{c}-1.4545^{* *} \\
(0.010)\end{array}$ & $\begin{array}{c}38.6243^{* * *} \\
(0.000)\end{array}$ & $\begin{array}{l}0.0311 \\
(0.859)\end{array}$ \\
\hline EquityTotal_TA & $\begin{array}{l}0.0703 \\
(0.171)\end{array}$ & $\begin{array}{l}0.2371 \\
(0.144)\end{array}$ & $\begin{array}{l}-0.0157 \\
(0.233)\end{array}$ \\
\hline RevenueBudgeted_TA & $\begin{array}{c}-0.0068 \\
(0.918)\end{array}$ & $\begin{array}{c}-0.3161 \\
(0.122)\end{array}$ & $\begin{array}{l}0.0162 \\
(0.340)\end{array}$ \\
\hline RevenueTotal_TA & $\begin{array}{c}0.5691^{* *} \\
(0.018)\end{array}$ & $\begin{array}{c}3.7745^{* * *} \\
(0.000)\end{array}$ & $\begin{array}{l}-0.0597 \\
(0.316)\end{array}$ \\
\hline PopPerEmp & $\begin{array}{c}-0.0007^{* * *} \\
(0.005)\end{array}$ & $\begin{array}{l}-0.0008 \\
(0.511)\end{array}$ & $\begin{array}{c}0.0001^{* * *} \\
(0.010)\end{array}$ \\
\hline population & $\begin{array}{l}0.0000 \\
(0.227)\end{array}$ & $\begin{array}{c}-0.0000^{*} \\
(0.090)\end{array}$ & $\begin{array}{c}-0.0000^{*} \\
(0.072)\end{array}$ \\
\hline number of FTE employees EOY & $\begin{array}{c}-0.0001^{*} \\
(0.084)\end{array}$ & $\begin{array}{c}-0.0014^{* * *} \\
(0.000)\end{array}$ & $\begin{array}{c}0.0000^{* *} \\
(0.015)\end{array}$ \\
\hline Constant & $\begin{array}{c}-0.4937^{* *} \\
(0.029)\end{array}$ & $\begin{array}{c}-27.4536^{* * *} \\
(0.000)\end{array}$ & $\begin{array}{l}0.1907 * \\
(0.059)\end{array}$ \\
\hline R-squared & 0.2495 & 0.9999 & 0.9910 \\
\hline Observations & 343 & 343 & 343 \\
\hline Number of LGAcode & 43 & 43 & 43 \\
\hline
\end{tabular}

Note: $p$ values in parentheses, significance marked as follows: ${ }^{* * *} p<0.01,{ }^{* *} p<0.05,{ }^{*} p<0.1$. Variables are as described in Table 1. Variables described in Table 1 which have been standardised by Total Assets are renamed with a suffix of "_TA". 
Table 8: Determinants of Depreciation and Asset Revaluation Reserve

\begin{tabular}{|c|c|}
\hline & SCA_TA \\
\hline$\frac{\text { Panel B - Lagged }}{\text { LogTotalAssets }}$ & $\begin{array}{l}-0.0000 \\
(0.559)\end{array}$ \\
\hline DEPN_TE (lagged one period) & $\begin{array}{l}0.0131 \\
(0.344)\end{array}$ \\
\hline$A R R \_T A$ (lagged one period) & $\begin{array}{l}-0.0000 \\
(0.656)\end{array}$ \\
\hline CFOnet_TA & $\begin{array}{l}-0.0000 \\
(0.748)\end{array}$ \\
\hline EmployeeExpenses_TA & $\begin{array}{l}0.0000 \\
(0.277)\end{array}$ \\
\hline EquityTotal_TA & $\begin{array}{l}0.0000 \\
(0.645)\end{array}$ \\
\hline RevenueBudgeted_TA & $\begin{array}{l}0.0000 \\
(0.381)\end{array}$ \\
\hline RevenueTotal_TA & $\begin{array}{l}-0.0000 \\
(0.805)\end{array}$ \\
\hline PopPerEmp & $\begin{array}{c}0.0001^{* *} \\
(0.037)\end{array}$ \\
\hline population & $\begin{array}{c}-228.4879 * \\
(0.073)\end{array}$ \\
\hline number of FTE employees EOY & $\begin{array}{c}48,269.0809 * \\
(0.074)\end{array}$ \\
\hline Constant & $\begin{array}{c}-0.0093 \\
(0.431)\end{array}$ \\
\hline R-squared & 0.0584 \\
\hline Observations & 300 \\
\hline Number of LGAcode & 43 \\
\hline
\end{tabular}


Table 9: Determinants of Contracts (Contracts over threshold, Materials \& Contracts expense, Materials \& Contracts payments)

Panel A: bottom quartile

(1) $\quad$ (2)

\begin{tabular}{|c|c|c|c|}
\hline & $S C A \_T A$ & MCE_TA & MCP_TA \\
\hline ICAREVAL_TA ${ }^{\text {winsorised(5\%,95\%) }}$ & -0.0205 & $\begin{array}{l}0.0055 \\
(0.458)\end{array}$ & $\begin{array}{l}0.0204 \\
(0.110)\end{array}$ \\
\hline \multirow[t]{2}{*}{ ICAREVAL_t1_TA ${ }^{\text {winsorised(5\%,95\%) }}$} & 0.0206 & 0.0017 & 0.0097 \\
\hline & (0.299) & $(0.766)$ & $(0.347)$ \\
\hline \multirow[t]{2}{*}{ ICA_t1_TA winsorised(5\%,95\%) } & -0.0095 & 0.0017 & 0.0019 \\
\hline & $(0.244)$ & $(0.475)$ & $(0.648)$ \\
\hline \multirow[t]{2}{*}{ CFONET_TA ${ }^{\text {winsorised(5\%,95\%) }}$} & 0.1583 & -0.0585 & -0.1319 \\
\hline & $(0.534)$ & $(0.392)$ & (0.178) \\
\hline \multirow{2}{*}{ EmployeeExpenses_TA winsorised(5\%,95\%) } & -0.2578 & -0.0181 & -0.0962 \\
\hline & $(0.395)$ & $(0.812)$ & $(0.367)$ \\
\hline \multirow[t]{2}{*}{ EquityTotal_TA winsorised(5\%,95\%) } & 0.0766 & 0.0145 & -0.0129 \\
\hline & $(0.581)$ & $(0.666)$ & $(0.791)$ \\
\hline \multirow[t]{2}{*}{ RevenueBudgeted_TA winsorised(5\%,95\%) } & -0.0482 & $0.1766^{* * *}$ & $0.3309 * * *$ \\
\hline & $(0.801)$ & $(0.001)$ & $(0.000)$ \\
\hline \multirow[t]{2}{*}{ RevenueTotal_TA winsorised(5\%,95\%) } & -0.0116 & -0.0359 & $-0.1057 *$ \\
\hline & $(0.937)$ & $(0.375)$ & $(0.081)$ \\
\hline \multirow[t]{2}{*}{ LogTotalAssets winsorised(5\%,95\%) } & 0.0077 & $-0.0086 * * *$ & $-0.0063^{*}$ \\
\hline & $(0.386)$ & $(0.000)$ & $(0.097)$ \\
\hline \multirow[t]{2}{*}{ Constant } & -0.1952 & $0.1727^{* * *}$ & $0.1490^{*}$ \\
\hline & $(0.270)$ & $(0.000)$ & $(0.060)$ \\
\hline R-squared & 0.0517 & 0.4387 & 0.3521 \\
\hline Observations & 65 & 65 & 65 \\
\hline Number of LGAcode & 19 & 19 & 19 \\
\hline \multirow[t]{2}{*}{ Panel B: top quartile } & (1) & (2) & (3) \\
\hline & SCA_TA & MCE_TA & MCP_TA \\
\hline \multirow[t]{2}{*}{ ICAREVAL_TA ${ }^{\text {winsorised(5\%,95\%) }}$} & 0.0284 & $0.0084 * *$ & 0.0041 \\
\hline & $(0.126)$ & $(0.016)$ & $(0.360)$ \\
\hline \multirow[t]{2}{*}{ ICAREVAL_t1_TA winsorised(5\%,95\%) } & -0.0054 & 0.0022 & 0.0012 \\
\hline & $(0.758)$ & $(0.476)$ & $(0.769)$ \\
\hline \multirow[t]{2}{*}{ ICA_t1_TA winsorised(5\%,95\%) } & -0.0024 & 0.0019 & 0.0014 \\
\hline & $(0.784)$ & $(0.298)$ & $(0.530)$ \\
\hline \multirow[t]{2}{*}{ CFONET_TA winsorised(5\%,95\%) } & 0.1290 & -0.0574 & $-0.1506 * *$ \\
\hline & $(0.672)$ & $(0.302)$ & $(0.035)$ \\
\hline \multirow[t]{2}{*}{ EmployeeExpenses_TA winsorised(5\%,95\%) } & -0.5961 & 0.0423 & 0.0007 \\
\hline & $(0.218)$ & $(0.718)$ & $(0.996)$ \\
\hline \multirow[t]{2}{*}{ EquityTotal_TA winsorised(5\%,95\%) } & 0.1009 & -0.0093 & -0.0192 \\
\hline & $(0.227)$ & $(0.716)$ & $(0.524)$ \\
\hline \multirow[t]{2}{*}{ RevenueBudgeted_TA winsorised(5\%,95\%) } & 0.1726 & 0.0724 & 0.0742 \\
\hline & $(0.435)$ & $(0.128)$ & (0.219) \\
\hline \multirow[t]{2}{*}{ RevenueTotal_TA winsorised(5\%,95\%) } & 0.0217 & $0.0734^{* *}$ & $0.0848 * *$ \\
\hline & $(0.890)$ & $(0.028)$ & $(0.046)$ \\
\hline \multirow[t]{2}{*}{ LogTotalAssets winsorised(5\%,95\%) } & -0.0014 & $-0.0044 * * *$ & $-0.0035^{* *}$ \\
\hline & $(0.751)$ & $(0.001)$ & $(0.026)$ \\
\hline \multirow[t]{2}{*}{ Constant } & -0.0534 & $0.1054^{* * *}$ & $0.0987^{* *}$ \\
\hline & $(0.697)$ & $(0.006)$ & $(0.033)$ \\
\hline R-squared & 0.1503 & 0.4026 & 0.3568 \\
\hline Observations & 82 & 82 & 82 \\
\hline Number of LGAcode & 18 & 18 & 18 \\
\hline
\end{tabular}

Note: $p$ values in parentheses, significance marked as follows: ${ }^{* * *} p<0.01,{ }^{* *} p<0.05,{ }^{*} p<0.1$. Variables are as described in Table 1. Variables described in Table 1 which have been standardised by Total Assets are renamed with a suffix of "_TA" and all variables have been winsorised by setting values below the $5^{\text {th }}$ percentile and above the $95^{\text {th }}$ percentile to those percentile values, respectively. 
Table 10: Determinants of CEO \& Management remuneration, by quartiles (winsorised variables)

Panel A: bottom quartile

(1) (2)

CEO_REMUN_TA MGT_REMUN_TA

\begin{tabular}{|c|c|c|}
\hline \multirow[t]{2}{*}{ ICAREVAL_TA ${ }^{\text {winsorised(5\%,95\%) }}$} & $-0.0002^{*}$ & -0.0002 \\
\hline & $(0.073)$ & $(0.458)$ \\
\hline \multirow[t]{2}{*}{ ICAREVAL_t1_TA winsorised(5\%,95\%) } & -0.0000 & 0.0001 \\
\hline & $(0.863)$ & (0.699) \\
\hline \multirow[t]{2}{*}{ ICA_t1_TA winsorised(5\%,95\%) } & -0.0000 & -0.0002 \\
\hline & $(0.518)$ & $(0.185)$ \\
\hline \multirow[t]{2}{*}{ CFONET_TA winsorised(5\%,95\%) } & 0.0003 & -0.0031 \\
\hline & $(0.797)$ & (0.509) \\
\hline \multirow[t]{2}{*}{ EmployeeExpenses_TA winsorised(5\%,95\%) } & $0.0028 * *$ & 0.0003 \\
\hline & $(0.018)$ & (0.961) \\
\hline \multirow[t]{2}{*}{ EquityTotal_TA winsorised(5\%,95\%) } & 0.0005 & 0.0048 \\
\hline & $(0.398)$ & (0.151) \\
\hline \multirow[t]{2}{*}{ RevenueBudgeted_TA winsorised(5\%,95\%) } & -0.0006 & 0.0026 \\
\hline & $(0.436)$ & $(0.462)$ \\
\hline \multirow[t]{2}{*}{ RevenueTotal_TA winsorised(5\%,95\%) } & 0.0007 & 0.0031 \\
\hline & $(0.277)$ & $(0.246)$ \\
\hline LogTotalAssets ${ }^{\text {winsorised(5\%,95\%) }}$ & $\begin{array}{c}-0.0002 * * * \\
(0.000)\end{array}$ & $\begin{array}{c}-0.0007 * * * \\
(0.000)\end{array}$ \\
\hline \multirow[t]{2}{*}{ Constant } & $0.0042^{* * *}$ & $0.0100 * * *$ \\
\hline & $(0.000)$ & $(0.008)$ \\
\hline R-squared & 0.5266 & 0.3867 \\
\hline Observations & 64 & 65 \\
\hline Number of LGAcode & 18 & 19 \\
\hline \multirow[t]{2}{*}{ Panel B: top quartile } & (1) & (2) \\
\hline & CEO_REMUN_TA & MGT_REMUN_TA \\
\hline \multirow[t]{2}{*}{ ICAREVAL_TA ${ }^{\text {winsorised(5\%,95\%) }}$} & 0.0000 & -0.0000 \\
\hline & $(0.726)$ & $(0.272)$ \\
\hline \multirow[t]{2}{*}{ ICAREVAL_t1_TA winsorised(5\%,95\%) } & -0.0000 & $0.0005^{* * *}$ \\
\hline & $(0.338)$ & $(0.005)$ \\
\hline \multirow{2}{*}{ ICA_t1_TA winsorised(5\%,95\%) } & -0.0000 & 0.0000 \\
\hline & $(0.259)$ & $(0.910)$ \\
\hline \multirow[t]{2}{*}{ CFONET_TA winsorised(5\%,95\%) } & 0.0001 & $-0.0127^{*}$ \\
\hline & $(0.953)$ & $(0.093)$ \\
\hline \multirow[t]{2}{*}{ EmployeeExpenses_TA winsorised(5\%,95\%) } & 0.0005 & -0.0082 \\
\hline & (0.795) & (0.545) \\
\hline \multirow[t]{2}{*}{ EquityTotal_TA winsorised(5\%,95\%) } & 0.0001 & -0.0004 \\
\hline & $(0.758)$ & $(0.881)$ \\
\hline \multirow[t]{2}{*}{ RevenueBudgeted_TA winsorised(5\%,95\%) } & 0.0011 & 0.0072 \\
\hline & $(0.202)$ & $(0.221)$ \\
\hline \multirow[t]{2}{*}{ RevenueTotal_TA winsorised(5\%,95\%) } & -0.0009 & 0.0024 \\
\hline & $(0.166)$ & $(0.562)$ \\
\hline \multirow[t]{2}{*}{ LogTotalAssets ${ }^{\text {winsorised(5\%,95\%) }}$} & $-0.0001 * * *$ & -0.0002 \\
\hline & $(0.000)$ & $(0.150)$ \\
\hline \multirow[t]{2}{*}{ Constant } & $0.0019 * * *$ & 0.0048 \\
\hline & $(0.000)$ & $(0.233)$ \\
\hline R-squared & 0.4101 & 0.1266 \\
\hline Observations & 79 & 82 \\
\hline Number of LGAcode & 18 & 18 \\
\hline
\end{tabular}

Note: $p$ values in parentheses, significance marked as follows: ${ }^{* *} p<0.01,{ }^{* *} p<0.05,{ }^{*} p<0.1$. Variables are as described in Table 1. Variables described in Table 1 which have been standardised by Total Assets are renamed with a suffix of "_TA" and all variables have been winsorised by setting values below the $5^{\text {th }}$ percentile and above the $95^{\text {th }}$ percentile to those percentile values, respectively. 
Table 11: Determinants of Operating and Capital Grants, by quartiles (winsorised variables)

Panel A: bottom quartile

(1) (2)

\begin{tabular}{|c|c|c|}
\hline & OpGrants_TA & CapGrants_TA \\
\hline \multirow[t]{2}{*}{ ICAREVAL_TA ${ }^{\text {winsorised }(5 \%, 95 \%)}$} & -0.0058 & $0.5128 *$ \\
\hline & $(0.301)$ & $(0.057)$ \\
\hline \multirow[t]{2}{*}{ ICAREVAL_t1_TA winsorised(5\%,95\%) } & -0.0010 & 0.0004 \\
\hline & $(0.811)$ & (0.999) \\
\hline \multirow[t]{2}{*}{$I C A \_t 2 \_T A^{\text {winsorised }(5 \%, 95 \%)}$} & 0.0009 & -0.0343 \\
\hline & $(0.657)$ & $(0.736)$ \\
\hline \multirow[t]{2}{*}{ CFOnet_TA winsorised(5\%,95\%) } & -0.0144 & $-4.5203 *$ \\
\hline & $(0.850)$ & $(0.093)$ \\
\hline \multirow[t]{2}{*}{ EmployeeExpenses_TA ${ }^{\text {winsorised }(5 \%, 95 \%)} 1$} & -0.0841 & -3.6772 \\
\hline & $(0.414)$ & $(0.203)$ \\
\hline \multirow[t]{2}{*}{ EquityTotal_TA winsorised(5\%,95\%) } & 0.0105 & -1.2162 \\
\hline & $(0.859)$ & $(0.423)$ \\
\hline \multirow[t]{2}{*}{ RevenueBudgeted_TA winsorised(5\%,95\%) } & -0.0634 & 0.0592 \\
\hline & $(0.230)$ & $(0.977)$ \\
\hline \multirow[t]{2}{*}{ RevenueTotal_TA winsorised(5\%,95\%) } & 0.0516 & $4.0946 * *$ \\
\hline & $(0.245)$ & $(0.014)$ \\
\hline \multirow[t]{2}{*}{ LogTotalAssets } & -0.0069 & -0.0755 \\
\hline & $(0.155)$ & $(0.719)$ \\
\hline \multirow[t]{2}{*}{ Constant } & 0.1474 & 2.5476 \\
\hline & $(0.133)$ & $(0.548)$ \\
\hline R-squared & 0.0000 & 0.3233 \\
\hline Observations & 48 & 48 \\
\hline Number of LGAcode & 14 & 14 \\
\hline \multirow[t]{2}{*}{ Panel B: top quartile } & (1) & (2) \\
\hline & OpGrants_TA & CapGrants_TA \\
\hline \multirow[t]{2}{*}{ ICAREVAL_TA ${ }^{\text {winsorised }(5 \%, 95 \%)}$} & -0.0000 & 0.0000 \\
\hline & $(0.660)$ & $(0.351)$ \\
\hline \multirow[t]{2}{*}{ ICAREVAL_t1_TA winsorised(5\%,95\%) } & 0.0030 & -0.0027 \\
\hline & $(0.225)$ & $(0.691)$ \\
\hline \multirow[t]{2}{*}{ ICA_t2_TA winsorised (5\%,95\%) } & -0.0004 & 0.0017 \\
\hline & $(0.819)$ & $(0.652)$ \\
\hline \multirow[t]{2}{*}{ CFOnet_TA winsorised(5\%,95\%) } & -0.0082 & -0.0137 \\
\hline & $(0.905)$ & $(0.936)$ \\
\hline \multirow[t]{2}{*}{ EmployeeExpenses_TA winsorised(5\%,95\%) } & 0.2257 & $-0.7444 * * *$ \\
\hline & $(0.105)$ & $(0.005)$ \\
\hline \multirow[t]{2}{*}{ EquityTotal_TA winsorised(5\%,95\%) } & $-0.0794 * * *$ & $0.0779 * *$ \\
\hline & $(0.004)$ & (0.029) \\
\hline \multirow[t]{2}{*}{ RevenueBudgeted_TA ${ }^{\text {winsorised }(5 \%, 95 \%)}$} & $-0.1134 * *$ & $-0.4979 * * *$ \\
\hline & $(0.033)$ & $(0.000)$ \\
\hline \multirow[t]{2}{*}{ RevenueTotal_TA winsorised(5\%,95\%) } & $0.0780 *$ & $0.9923 * * *$ \\
\hline & $(0.062)$ & $(0.000)$ \\
\hline \multirow[t]{2}{*}{ LogTotalAssets } & $-0.0056 * * *$ & -0.0007 \\
\hline & $(0.000)$ & $(0.742)$ \\
\hline \multirow[t]{2}{*}{ Constant } & $0.2025 * * *$ & -0.0731 \\
\hline & $(0.000)$ & $(0.223)$ \\
\hline R-squared & 0.6231 & 0.8664 \\
\hline Observations & 74 & 74 \\
\hline Number of LGAcode & 18 & 18 \\
\hline
\end{tabular}

Note: $p$ values in parentheses, significance marked as follows: ${ }^{* *} p<0.01,{ }^{* *} p<0.05, * p<0.1$. Variables are as described in Table 1. Variables from Table 1 have been standardised by Total Assets (a suffix of “_TA") and all variables have been winsorised as described in Table 9. 
Table 12: Determinants of Depreciation and Asset Revaluation Reserve, by quartiles (winsorised variables)

Panel A: bottom quartile

(1)

$D E P N \_T E$

SCA_TA ${ }^{\text {winsorised(5\%,95\%) }}$

DEPN_TE winsorised(5\%,95\%)

$A R R \_T A$ winsorised(5\%,95\%)

CFONET_TA winsorised (5\%,95\%)

EmployeeExpenses_TA winsorised(5\%,95\%)

EquityTotal_TA winsorised(5\%,95\%)

RevenueBudgeted_TA winsorised(5\%,95\%)

RevenueTotal_TA winsorised(5\%,95\%)

LogTotalAssets ${ }_{\text {winsorised(5\%,95\%) }}$

Constant

R-squared

Observations

Number of LGAcode

0.4737

$(0.131)$

\begin{tabular}{|l|l}
0.0491 \\
$(0.229)$
\end{tabular}

\begin{tabular}{|c|c|c|c|}
\hline Panel B: top quartile & $\begin{array}{c}1) \\
D E P N_{-} T E\end{array}$ & $\begin{array}{c}(2) \\
A R R \_T A\end{array}$ & $\begin{array}{c}\text { (3) } \\
S C A \_T A\end{array}$ \\
\hline SCA_TA winsorised(5\%,95\%) & $\begin{array}{l}0.6013^{*} \\
(0.052)\end{array}$ & $\begin{array}{l}0.5411 \\
(0.219)\end{array}$ & \\
\hline$D E P N \_T E$ winsorised(5\%,95\%) & & & $\begin{array}{l}0.0584 \\
(0.128)\end{array}$ \\
\hline$A R R \_T A$ winsorised(5\%,95\%) & & & $\begin{array}{l}0.0019 \\
(0.872)\end{array}$ \\
\hline CFONET_TA winsorised(5\%,95\%) & $\begin{array}{c}-1.6835^{* *} \\
(0.044)\end{array}$ & $\begin{array}{l}-0.7311 \\
(0.532)\end{array}$ & $\begin{array}{l}-0.0601 \\
(0.845)\end{array}$ \\
\hline EmployeeExpenses_TA winsorised(5\%,95\%) & $\begin{array}{c}-4.1609^{* *} \\
(0.011)\end{array}$ & $\begin{array}{c}6.6566^{* *} \\
(0.023)\end{array}$ & $\begin{array}{l}-0.7823 \\
(0.137)\end{array}$ \\
\hline EquityTotal_TA winsorised(5\%,95\%) & $\begin{array}{c}-0.8959 * * * \\
(0.007)\end{array}$ & $\begin{array}{c}-2.0078^{* *} \\
(0.030)\end{array}$ & $\begin{array}{c}0.2152^{* *} \\
(0.017)\end{array}$ \\
\hline RevenueBudgeted_TA winsorised(5\%,95\%) & $\begin{array}{l}0.9384 \\
(0.176)\end{array}$ & $\begin{array}{l}-0.6257 \\
(0.545)\end{array}$ & $\begin{array}{l}0.3378 \\
(0.134)\end{array}$ \\
\hline RevenueTotal_TA winsorised(5\%,95\%) & $\begin{array}{l}0.8326^{*} \\
(0.097)\end{array}$ & $\begin{array}{l}-1.0755 \\
(0.155)\end{array}$ & $\begin{array}{l}0.0168 \\
(0.924)\end{array}$ \\
\hline LogTotalAssets ${ }^{\text {winsorised(5\%,95\%) }}$ & $\begin{array}{l}0.0198 \\
(0.254)\end{array}$ & $\begin{array}{c}0.3172 * * * \\
(0.000)\end{array}$ & $\begin{array}{l}-0.0020 \\
(0.710)\end{array}$ \\
\hline Constant & $\begin{array}{l}0.6311 \\
(0.190)\end{array}$ & $\begin{array}{c}-4.6361 * * * \\
(0.000)\end{array}$ & $\begin{array}{l}-0.1668 \\
(0.179)\end{array}$ \\
\hline R-squared & 0.3010 & 0.3188 & 0.1694 \\
\hline Observations & 87 & 87 & 87 \\
\hline Number of LGAcode & 18 & 18 & 18 \\
\hline
\end{tabular}

Note: $p$ values in parentheses, significance marked as follows: ${ }^{* * *} p<0.01,{ }^{* *} p<0.05,{ }^{*} p<0.1$. Variables are as described in Table 1. Variables from Table 1 have been standardised by Total Assets (a suffix of “_TA") and all variables have been winsorised as described in Table 9.
0.0100

(0.369)

0.1553

(0.497)

$-0.0699$

$(0.792)$

0.0975

$(0.298)$

0.0255

(0.879)

$-0.0193$

(0.879)

$-0.0040^{*}$

\begin{tabular}{l|l|r}
$(0.107)$ & $(0.855)$ & $(0.097)$ \\
$0.8714 * * *$ & -0.7654 & -0.0119
\end{tabular}

$\begin{array}{llll}(0.000) & (0.442) & (0.895)\end{array}$

\begin{tabular}{l|l|l}
0.5962 & 0.1173 & 0.1655
\end{tabular}

\begin{tabular}{l|l|l}
86 & 86 & 86
\end{tabular}

\begin{tabular}{l|l|l}
23 & 23 & 23
\end{tabular}

86

